\title{
Greenhouse Gas Balance of Sphagnum Farming on Highly Decomposed Peat at Former Peat Extraction Sites
}

\author{
Jan Oestmann, ${ }^{1 *}$ Bärbel Tiemeyer, ${ }^{1}$ Dominik Düvel, ${ }^{1}$ Amanda Grobe,${ }^{2}$ and \\ Ullrich Dettmann ${ }^{1,3}$
}

\begin{abstract}
${ }^{1}$ Thünen Institute of Climate-Smart Agriculture, Bundesallee 65, 38116 Braunschweig, Germany; ${ }^{2}$ Institute of Environmental Planning, Leibniz University Hannover, Herrenhäuser Str. 2, 30419 Hannover, Germany; ${ }^{3}$ Institute of Soil Science, Leibniz University Hannover, Herrenhäuser Str. 2, 30419 Hannover, Germany
\end{abstract}

\begin{abstract}
For two years, we quantified the exchange of carbon dioxide $\left(\mathrm{CO}_{2}\right)$, methane $\left(\mathrm{CH}_{4}\right)$ and nitrous oxide $\left(\mathrm{N}_{2} \mathrm{O}\right)$ at two different large-scale Sphagnum farming sites. At both, peat extraction left a shallow layer of highly decomposed peat and low hydraulic conductivities. One site was characterized by preceding multi-annual inundation and irrigated by ditches, while the other one was inoculated directly after peat extraction and irrigated by ditches and drip irrigation. Further, GHG emissions from an irrigation polder and the effect of harvesting Sphagnum donor material at a near-natural reference site were determined. GHG mitigation potentials lag behind the results of less decomposed sites, although our results were also affected by the extraordinary hot and dry summer 2018. $\mathrm{CO}_{2}$ exchanges ranged between -0.6 and $2.2 \mathrm{t} \mathrm{CO}_{2}-\mathrm{C} \mathrm{ha}^{-1}$
\end{abstract}

Received 16 July 2020; accepted 16 May 2021; published online 21 July 2021

Supplementary Information: The online version contains supplementary material available at https://doi.org/10.1007/s10021-021-0065 9-z.

Author Contributions BT, JO and UD designed the study; JO, DD and AG performed the research; UD, BT, DD and JO wrote code; all authors contributed to data analysis; JO wrote the first draft, and all authors contributed to the final manuscript.

*Corresponding author; e-mail: jan_oestmann@yahoo.de $\mathrm{y}^{-1}$ and were mainly influenced by low water table depths. $\mathrm{CH}_{4}$ emissions were low with the exception of plots with higher Eriophorum covers, while fluctuating water tables and poorly developing plant covers led to considerable $\mathrm{N}_{2} \mathrm{O}$ emissions at the ditch irrigation site. The removal of the upper vegetation at the near-natural site resulted in increased $\mathrm{CH}_{4}$ emissions and, on average, lowered $\mathrm{CO}_{2}$ emissions. Overall, best plant growth and lowest GHG emissions were measured at the previously inundated site. At the other site, drip irrigation provided more favourable conditions than ditch irrigation. The size of the area needed for water management (ditches, polders) strongly affected the areal GHG balances. We conclude that Sphagnum farming on highly decomposed peat is possible but requires elaborate water management.

\section{HighLIGHTS}

- Sphagnum farming is possible on highly decomposed peat.

- GHG exchange was mainly affected by water table depth and vegetation development.

- $\mathrm{CH}_{4}$ and $\mathrm{N}_{2} \mathrm{O}$ may influence GHG balances of inadequately managed sites. 


\section{INTRODUCTION}

Drained and intensively used peatlands emit large amounts of greenhouse gases (GHG) into the atmosphere (Waddington and Price 2000; Tiemeyer and others 2020). Re-wetting these areas as soon as possible is the most effective measure to mitigate climate warming in the long term (Günther and others 2020; Wilson and others 2016b). However, raising water table depths (WTD) hinders conventional land use. Ecological and economic goals could be combined by implementing the concept of paludiculture, that is, the production of biomass under wet and peat preserving conditions using suitable wetland crops (Wichtmann and others 2016). Under nutrient-poor and acidic conditions, that is, on bog peat, the cultivation of peat mosses (Sphagnum farming) is the most promising land-use option (Gaudig and others 2018). Harvested moss fragments can be spread in degraded peatlands in order to accelerate vegetation restoration (Quinty and Rochefort 2003) or Sphagnum fibres can be used as a sustainable resource in horticultural substrates (Emmel 2008), substituting fossil weakly decomposed ('white') peat and this way relieving the pressure of ongoing peat extraction on pristine peatlands.

Besides providing habitat for endangered flora (Gaudig and Krebs 2016) and fauna (Muster and others 2015; Zoch and Reich 2020), re-wetting, for example, for Sphagnum farming has major impact on the GHG exchange of the cultivation sites. If water tables can be kept close to ground surface, carbon dioxide $\left(\mathrm{CO}_{2}\right)$ emissions can be reduced, stopped or even reversed (Wilson and others 2016a). Previous studies in northwest Germany hint towards a rapid recovery of Sphagnum farming sites as sinks of atmospheric carbon (Beyer and Höper 2015; Günther and others 2017). On the other hand, quasi-natural hydrological conditions favour the production of methane $\left(\mathrm{CH}_{4}\right)$. On average, $\mathrm{CH}_{4}$ emissions of classically re-wetted sites are comparable to those of natural sites (Wilson and others 2016a). $\mathrm{CH}_{4}$ emissions from Sphagnum cultivation sites have so far been found to be very low (Beyer and Höper 2015; Günther and others 2017) due to the strictly controlled water tables and the low abundance of aerenchymous species. Drained peatlands can release relevant amounts of nitrous oxide $\left(\mathrm{N}_{2} \mathrm{O}\right)$ (Regina and others 1996; Tiemeyer and others 2020), whereas the $\mathrm{N}_{2} \mathrm{O}$ emissions of Sphagnum farming field sites are close to zero (Beyer and Höper 2015; Günther and others 2017).
In this study, the cultivation sites were established following the moss layer transfer technique (Quinty and Rochefort 2003). Data on the effect of harvesting donor material are scarce, but need to be considered when assessing the GHG balance of Sphagnum cultivation. It is suggested that harvested sites recover quickly (Silvan and others 2017; Krebs and others 2018; Guene-Nanchen and others 2019) and might return to their pre-disturbance carbon balance naturally within a few years (Murray and others 2017), but further research is of special importance in areas such as Germany where nearnatural sites are extremely rare.

Peat mosses possess no roots and rely on precipitation and capillary water supply. As moisture controls Sphagnum photosynthesis and productivity (McNeil and Waddington 2003), the adjustment of a high and stable water table is the key factor of a successful cultivation of peat mosses (Pouliot and others 2015). Previous Sphagnum farming trials have been relatively small in scale $(0.10$ to 1.1 ha, Brown and others 2017; Beyer and Höper 2015; Günther and others 2017), where WTDs are relatively easy to control. Thus, there is still a gap in knowledge on which irrigation technique is most suitable in large-scale peat moss cultivation regarding optimum growth of mosses and maximum GHG mitigation. The most common techniques are subsurface irrigation (Brown and others 2017, Gaudig and others 2017) and irrigation ditches (Beyer and Höper 2015; Brown and others 2017; Günther and others 2017), while drip irrigation has not yet been tested.

In contrast to previous studies, this study is the first to explore the feasibility and the GHG exchange of large-scale Sphagnum farming on shallow, highly decomposed peat remaining after industrial peat extraction. The high degree of decomposition of the peat imposes new challenges to large-scale Sphagnum farming as the concomitant low porosity and hydraulic conductivity (Liu and Lennartz 2019) cause strong fluctuations of WTDs and poor water supply from ditches. This raises the question whether highly decomposed peat can support Sphagnum farming.

A further challenge is the irrigation water: surface and groundwater might be unsuitable due to high nutrient, electric conductivity (EC) and $\mathrm{pH}$ levels, while rainwater storage requires space. 'Classical' bog re-wetting after peat extraction is frequently done by creating water-filled polders separated by dams, which are to undergo succession towards peatland vegetation (Blankenburg 2004). Such polders could also be used to store and deliver water to Sphagnum cultivation sites, but 
need to be included into an areal GHG balance of a Sphagnum cultivation system. Such data are important as high emissions have been reported for inundated fens (Franz and others 2016; Hahn and others 2015).

Vascular plants emerge even in strongly controlled Sphagnum farming systems. They could, on the one hand, compete with Sphagnum for resources and are unwanted in the produced substrate. On the other hand, vascular 'shelter' plants have been shown to be beneficial for Sphagnum development by creating microhabitats with higher soil moisture and protection from excess solar radiation and wind (McNeil and Waddington 2003; McCarter and Price 2015). Further, species composition will influence the GHG exchange, for example, by increasing $\mathrm{CH}_{4}$ emissions via aerenchymous tissues (Gray and others 2013).

Consequently, the objective of this study is to determine areal GHG balances of large-scale Sphagnum farming on a highly decomposed peat soil including emissions from the irrigation system, dams (using literature data) and projected harvest in comparison with a near-natural bog. Special emphasis is put on the influence of different irrigation techniques (ditch irrigation, drip irrigation and a combination of ditch irrigation and preceding multi-annual inundation) and on the effect of harvesting Sphagnum donor material at the nearnatural site.

\section{Materials AND Methods}

\section{Study Sites and Implementation of the Sphagnum Cultivation Areas}

We measured GHGs at two Sphagnum cultivation areas ('Provinzialmoor', $52^{\circ} 40^{\prime} \mathrm{N}, 07^{\circ} 06^{\prime} \mathrm{E}$ and 'Drenth', $52^{\circ} 41^{\prime} \mathrm{N}, 07^{\circ} 05^{\prime} \mathrm{E}$ ) and a near-natural peat bog ('Meerkolk', 52 $38^{\prime} \mathrm{N}, 07^{\circ} 08^{\prime} \mathrm{E}$ ) from March 2017 to March 2019 (Fig. 1). All sites are situated approximately $20 \mathrm{~km}$ northwest of Lingen, Lower Saxony, Germany. The climate is oceanic with an average annual precipitation of $791 \mathrm{~mm}$ and an average annual temperature of $9.8^{\circ} \mathrm{C}$ (1971-2000, Lingen, German Weather Service).

Meerkolk, a last remainder of a once vast peatland complex, is a former bog pool characterized by partially floating peat moss and cotton grass mats with a peat thickness of about $350 \mathrm{~cm}$. The upper $53 \mathrm{~cm}$ are weakly decomposed, and the lower part is highly decomposed with a high water content (Table 1). The site can be classified as an Ombric Fibric Histosol (IUSS Working Group WRB 2015). The dominating plant species are Sphagnum papil- losum, Sphagnum pulchrum, Sphagnum cuspidatum, Rhynchospora alba, Molinia caerulea, Vaccinium oxycoccos, Erica tetralix, Drosera rotundifolia and Eriophorum angustifolium. Close to the measurement plots, the upper $5 \mathrm{~cm}$ of Sphagnum vegetation was harvested and used for the inoculation of parts of Provinzialmoor (P-MIX). As the area is-as nearly all potential donor sites in Germany-strictly protected, mosses were selectively manually harvested. Meerkolk is hereafter referred to as nearnatural reference site. GHGs were measured at a control site (M-NAT) and at a harvest site where the upper $5 \mathrm{~cm}$ of vegetation were removed in April 2017 (M-HAR).

Both Provinzialmoor and Drenth are former sites of industrial peat extraction with remaining peat thicknesses of about $90 \mathrm{~cm}$ and $45 \mathrm{~cm}$, respectively. Both sites are Ombric Hemic Histosols. The lower part of the profile is moderately decomposed fen peat overlying a relictic gley and the upper part moderately to highly decomposed bog peat. The major difference between the two areas is that Provinzialmoor has been re-wetted in 2008 after the termination of peat extraction as a system of large ( $\sim 1.6$ to 4.2 ha) shallow polders, while Drenth is a narrow strip of seven polders installed in 2015 directly after terminating peat extraction without any previous re-wetting. Thus, Drenth is not surrounded by water bodies and re-wetted peatlands but by ongoing peat extraction. The inoculation of Sphagnum mosses was performed following the moss layer transfer technique (Quinty and Rochefort 2003). In brief, small fragments of peat mosses were spread evenly and covered with straw mulch (details in Graf and others 2017) and developed into new moss plants. Along with the Sphagnum mosses, vascular plants were also transferred. In order to prevent negative feedback of dominant vascular plants on peat moss development and substrate quality, the cultivation sites were mowed 1-2 times a year.

In Drenth, water is pumped from two ponds, which were additionally replenished with deeper ground water in dry periods. Excess irrigation water is channelled back to the ponds. The sites were inoculated with Sphagnum papillosum in October 2015. Due to the poor growth of mosses, parts were re-inoculated with Sphagnum palustre in April 2017. GHGs were measured at two of these polders (0.4 ha each): one irrigated by ditches (D-DITCH) and the other one by drip irrigation (D-DRIP). Drip irrigation was installed in April 2017 and the site was irrigated via subsurface drain pipes until then.

In Provinzialmoor, one of the polders (2.3 ha) was prepared for Sphagnum cultivation in 2015 by 


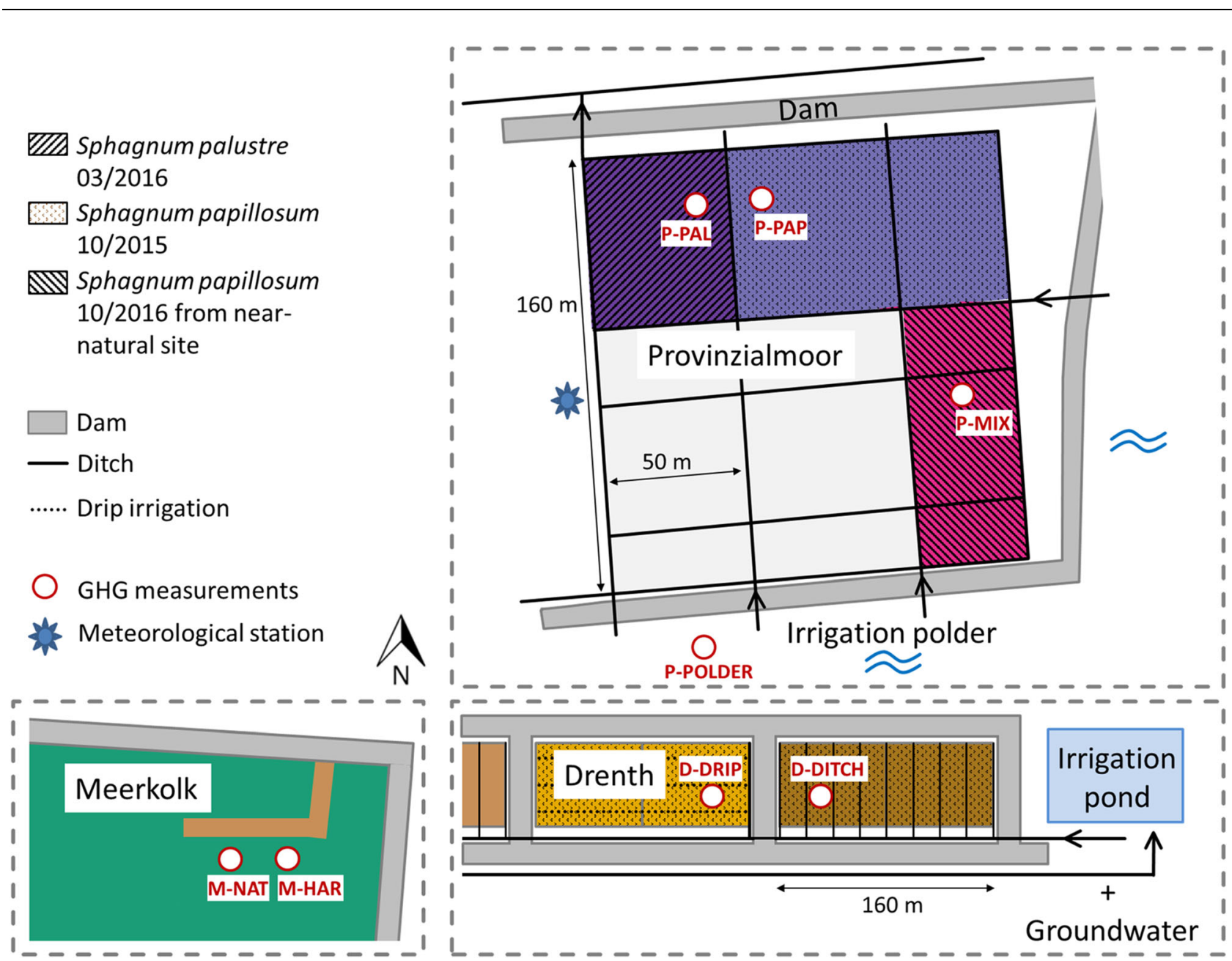

Figure 1. Scheme (not true-to-scale) of study sites (near-natural area Meerkolk and two cultivation areas Provinzialmoor and Drenth) after Graf and others (2020, modified). The background colours of the respective sites are maintained in all figures.

lowering the water table to the peat surface and profiling the ground. Different parts were inoculated with different peat moss species, that is, with Sphagnum papillosum in October 2015 (P-PAP), with Sphagnum palustre in March 2016 (P-PAL) and with a mix of Sphagnum hummock species from Meerkolk in October 2016 (P-MIX), although Sphagnum papillosum was the dominant species (Fig. 1). Water is supplied by the surrounding polders and is distributed via shallow ditches. To avoid inundation, surplus water is discharged to a drainage ditch. Unfortunately, drainage pipes (30 m drain spacing) have been discovered and destroyed only after termination of measurements. GHGs were also measured at the southern irrigation polder ( $\mathrm{P}$ POLDER) which was subjected to seasonal fluctuations of the water table $(-0.21$ to $0.56 \mathrm{~m})$. The measurement plots are located approximately $6 \mathrm{~m}$ away from the shore, with a sparse cover of submerged peat moss (Sphagnum cuspidatum).

\section{Environmental Parameters}

\section{Hydrological and Meteorological Characteristics}

A meteorological station in Provinzialmoor (Fig. 1) measured soil temperature $(2 \mathrm{~cm})$, air temperature and relative humidity $(2 \mathrm{~m})$, wind speed, photosynthetic active radiation and global radiation. All hydro-meteorological data were recorded in 30min intervals. Each GHG measurements site consisted of three replicate plots, and at all plots, soil temperatures $(2 \mathrm{~cm})$ were measured from June 2017 onwards. At the meteorological station, 15\% of the temperature and $2 \%$ of radiation data were missing and filled with data of the German Weather Service (station Lingen, $20 \mathrm{~km}$ away). In Meerkolk (M-NAT), 14\% of soil temperature values were missing and replaced by meteorological station data. In Drenth (D-DRIP) and Provinzialmoor (P-MIX), it was $29 \%$ and $23 \%$, respectively. 


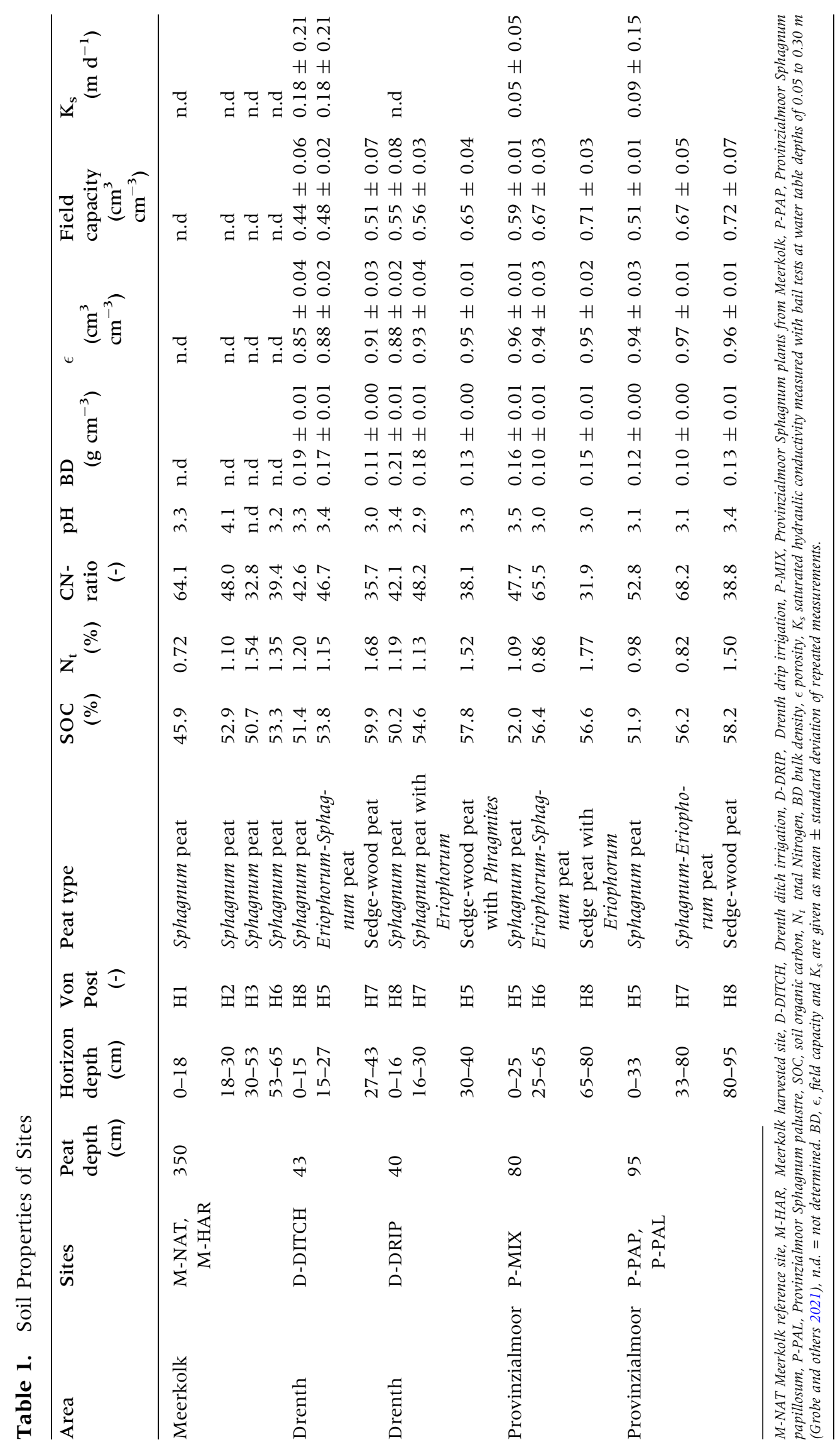


At sites M-NAT, D-DRIP and P-MIX, near-surface soil moistures were recorded using GS3 capacitance sensors (Decagon Devices Inc., Pullman, WA, USA). Volumetric water contents $\theta\left(\mathrm{cm}^{3} \mathrm{~cm}^{-3}\right)$ were calculated from dielectric permittivities using the standard calibration of the device for potting and peat soils. To exclude the impact of freezing on the dielectric permittivity, values at soil temperature below $2{ }^{\circ} \mathrm{C}$ were discarded. Measurements of $\theta$ were transformed to water-filled pore space (WFPS) by dividing $\theta$ with the maximum $\theta$ of the time series. Additionally, relative humidity was measured near the soil surface (IST AG, EbnatKappel, Switzerland).

Monitoring wells (slotted PVC tubes) were installed in the peat at all plots. To avoid measurements of deeper groundwater, they were installed in the peat layer only and thus fell periodically dry. Water table depth (WTD) was measured using Mini-Divers in combination with Baro-Divers for atmospheric pressure correction (Eijkelkamp, Giesbeek, the Netherlands). In the following, WTD below ground is noted with a negative sign and vice versa.

\section{Soil Properties}

At all study sites, soil profiles were dug. If sites were very close to each other, a profile was shared to minimize disturbance of the area (Table 1). From each horizon, samples for the determination of physical (six steel rings with a volume of $244.29 \mathrm{~cm}^{3}$ each) and chemical properties (grab samples) were taken. The degree of humification was determined according to von Post, and carbon $(\mathrm{C})$ and nitrogen $(\mathrm{N})$ contents were measured using an elemental analyser (LECO Corporation, St. Joseph, Michigan, USA).

Bulk density (BD) and porosity $(\epsilon)$ were determined as part of evaporation experiments with standard mass calculations based on the sample weight at the beginning and end of the experiment. Field capacity $(\theta$ at $\mathrm{pF} 1.8-\theta$ at $\mathrm{pF} 4.2$; pressure heads $h(\mathrm{~cm})$ are expressed as $\mathrm{pF}=\log 10(h))$ was determined with soil hydraulic properties using the bimodal hydraulic function of van Genuchten (1980) (Durner 1994) derived by evaporation experiments using the 'inverse method' described in Dettmann and others (2019).

\section{Water Quality}

Biweekly, soil water samples were taken at each site and from the irrigation pond in Drenth and polders in Provinzialmoor. EC and $\mathrm{pH}$ values were measured in situ (WTW, Weilheim, Germany).
Samples were filtered to $0.45 \mu \mathrm{m}$ (PES, Merck Millipore, Tullagreen, Ireland), and concentrations of nitrate $\left(\mathrm{NO}_{3}{ }^{-}\right)$, ammonium $\left(\mathrm{NH}_{4}{ }^{+}\right)$, phosphate $\left(\mathrm{PO}_{4}{ }^{3-}\right)$, sulphate $\left(\mathrm{SO}_{4}{ }^{2-}\right)$ and calcium $\left(\mathrm{Ca}^{2+}\right)$ were determined by ion chromatography (850 Professional Ion Chromatograph, Metrohm, Filderstadt, Germany). Concentrations of dissolved organic carbon (DOC) were calculated as the difference between total carbon and total inorganic carbon (DimaTOC 2000, Dimatec, Essen, Germany).

\section{Vegetation Characteristics}

Every spring and autumn, vegetation cover (mosses and vascular plants) and species composition were classified according to the Londo scale (Londo 1976) at each measurement plot. In addition, heights of Sphagnum lawns were recorded. The harvested biomass at the donor site (M-HAR) and the mowed vascular plants at the cultivation sites were dried to determine biomass. Subsequently, C and $\mathrm{N}$ contents were determined by elemental analysis (LECO Corporation, St. Joseph, Michigan, USA).

\section{Determination of Greenhouse Gas Balances}

GHGs were measured using manual static chambers (Livingston and Hutchinson 1995) at 8 sites (Fig. 1, Table 1). A 'site' represents a management/ vegetation type in one of the three study areas 'Meerkolk', 'Provinzialmoor' and 'Drenth' and consists of three 'plots' as measurement replicates. GHG measurements were taken for two years. The period from 16 March 2017 to 15 March 2018 will hereafter be referred to as 2017 and the period from 16 March 2018 to 15 March 2019 as 2018. We follow the atmospheric sign convention and emissions of GHG are specified as positive values.

All plots were accessible by boardwalks in order to minimize soil disturbances. During measurements, chambers were placed on permanently installed PVC frames and were fixed gas-tightly via a rubber seal and clamps. Fans mixed the air inside the chambers in order to avoid concentration differences. An opening in the chamber wall, which was closed with a rubber plug after placement, prohibited possible pressure differences during the placement of the chambers. Additionally, a vent tube prevented differences in pressure between inside and surrounding air. When necessary, transparent chambers were cooled with icepacks. At the irrigation polder (P-POLDER), buoyant frames with a water-filled u-shape were deployed. The frames were able to follow the WTD of the 
polder and held in position by thin steel poles. Before measurements, they were fixed to the poles.

\section{Carbon Dioxide}

\section{Measurement and Flux Calculation}

Fluxes of $\mathrm{CO}_{2}$ were measured monthly in diurnal campaigns using transparent and opaque chambers $(78 \times 78 \times 50 \mathrm{~cm}$, transparent polycarbonate and PVC) to determine the net ecosystem exchange (NEE) and ecosystem respiration $\left(R_{\text {eco }}\right)$, respectively.

Campaigns started with one set of $\mathrm{R}_{\text {eco }}$ measurements before sunrise, followed by one set of NEE measurements at sunrise and then continued in alternation until the maximum light intensity was reached at noon and the maximum soil temperature was reached in the afternoon. If possible, measurements were taken on sunny days to cover the whole range of environmental parameters. A minimum of four transparent and four opaque fluxes was measured per plot and campaign day. The $\mathrm{CO}_{2}$ concentration of the chamber air was measured with an infrared gas analyser (LI-820, LICOR, Lincoln, Nebraska, USA) during chamber closure times of 120 (NEE) and $180\left(R_{\text {eco }}\right)$ seconds. Additionally, air temperature and humidity (Rotronic GmbH, Ettlingen, Germany) were recorded and the $\mathrm{CO}_{2}$ concentrations were corrected for water vapour concentrations (Webb and others 1980).

Fluxes were calculated using the linear regression of a moving window with the highest coefficient of determination $\left(\mathrm{R}^{2}\right)$. The length of the moving window was adjusted according to the solar declination between $40 \mathrm{~s}$ at the longest day and $50 \mathrm{~s}$ at the shortest day. This was necessary as chamber air temperatures rapidly increased during summer and low fluxes required longer moving windows during winter. Fluxes with $R^{2}<0.75$ were excluded from further calculations unless the increase or decrease of the $\mathrm{CO}_{2}$ concentration was smaller than $3 \%$ of the mean concentration. If the change of photosynthetic active radiation (PAR) exceeded a threshold of $10 \%$ of the initial value and/or the change of air temperature inside the chamber was higher than $1.5^{\circ} \mathrm{C}$, no flux was calculated.

\section{Calculation of Annual Balances}

To account for the seasonal development in vegetation response to environmental conditions, we used a campaign-based approach for annual bal- ances (for example, Leiber-Sauheitl and others 2014).

First, response functions relating $R_{\text {eco }}$ to soil temperature were parameterized for each campaign day using the temperature dependent Arrhenius-type model of Lloyd and Taylor (1994):

$$
R_{\text {eco }}(T)=R_{\text {ref }} \times \exp \left[E_{0} \times\left(\frac{1}{T_{\text {ref }}-T_{0}}-\frac{1}{T-T_{0}}\right)\right]
$$

where $T$ is the measured soil temperature, $T_{\text {ref }}$ the reference temperature of $283.15 \mathrm{~K}$ and $T_{0}$ the temperature constant for the start of biological processes $(227.13 \mathrm{~K})$ and $R_{\text {ref }}$ (respiration at the reference temperature $\left.\left(\mathrm{mg} \mathrm{CO} \mathrm{CO}_{2}-\mathrm{C} \mathrm{m}^{-2} \mathrm{~h}^{-1}\right)\right)$ and $E_{0}$ (an activation-like parameter $\left.(\mathrm{K})\right)$ are the estimated parameters. If the difference between minimum and maximum temperatures was smaller than $1.5^{\circ} \mathrm{C}$ during the campaign day, the median of all $R_{\text {eco }}$ fluxes was used as $R_{\text {ref }}$ in Eq. 1 .

Secondly, using these parameters and halfhourly data of soil temperature, annual time series of $R_{\text {eco }}$ were interpolated for each site (LeiberSauheitl and others 2014). For every time point, $R_{\text {eco }}$ was calculated as the distance weighted mean of the two values derived by using the parameters of the previous and subsequent campaign.

Thirdly, gross primary production (GPP) was calculated as the difference between measured NEE and the nearest modelled $R_{\text {eco }}$ flux. For each campaign, the rectangular hyperbolic light response equation based on the Michaelis-Menten (Johnson and Goody 2011) kinetics was parameterized (Falge and others 2001):

$\mathrm{GPP}(\mathrm{PAR})=\frac{\mathrm{GPP} 2000 \times \alpha \times \mathrm{PAR}}{\mathrm{GPP} 2000+\alpha \times \mathrm{PAR}-\frac{\mathrm{GPP} 2000}{2000 \mu \mathrm{mol} \mathrm{m}^{-2} \mathrm{~s}^{-1}} \times \mathrm{PAR}}$

where PAR is the photon flux density of the photosynthetic active radiation $\left(\mu \mathrm{mol} \mathrm{m} \mathrm{m}^{-2} \mathrm{~s}^{-1}\right)$ and GPP2000 (the rate of carbon fixation at a PAR value of $2000\left(\mathrm{mg} \mathrm{CO}_{2}-\mathrm{C} \mathrm{m}^{-2} \mathrm{~h}^{-1}\right)$ ) and $\alpha$ (the light use efficiency (mg CO $\left.{ }_{2}-\mathrm{C} \mathrm{m}^{-2} \mathrm{~h}^{-1} / \mu \mathrm{mol} \mathrm{m}{ }^{-2} \mathrm{~s}^{-1}\right)$, that is, the initial slope of the fitted curve) are the estimated parameters. The PAR data of the measurement campaigns were corrected by a factor of 0.95 as the transparent chambers slightly reduce light transmission (PS-Plastic, Eching, Germany). If GPP parameters could not be fitted, the respective campaign was combined with the nearest campaign which best resembled the campaign's environmental conditions, that is, ranges of PAR and GPP. This was especially the case at the polder site (PPOLDER), where fluxes were low and variable and 
all campaigns were pooled. Annual time series of GPP were interpolated in analogy to $R_{\text {eco }}$ using the campaign parameters and half-hourly PAR data. The effect of cutting vegetation on the GPP interpolation of the near-natural donor site (M-HAR) was accounted for by setting the GPP parameters to zero at this day. NEE values were obtained by summing up GPP and $R_{\text {eco. }}$.

Finally, annual balances and uncertainties of NEE were estimated by bootstrapping. The response functions for $\mathrm{R}_{\mathrm{eco}}$ and GPP were fitted again using random resamples of the campaign fluxes with replacement (number of bootstraps $=1000$ ). From the bootstrapped fits, standard errors were calculated.

\section{Methane and Nitrous Oxide}

\section{Measurement and Flux Calculation}

Fluxes of $\mathrm{CH}_{4}$ and $\mathrm{N}_{2} \mathrm{O}$ were determined fortnightly using opaque chambers. Over a total closure time of 80 min, five consecutive chamber air gas samples were collected using semi-automatic sampling devices directly after placing the chamber and every $20 \mathrm{~min}$ from then on. Concentrations of $\mathrm{CO}_{2}, \mathrm{CH}_{4}$ and $\mathrm{N}_{2} \mathrm{O}$ were measured in the laboratory using a gas chromatograph (Shimadzu, Kyoto, Japan) equipped with an electron capture detector (ECD) for analysing $\mathrm{CO}_{2}$ and $\mathrm{N}_{2} \mathrm{O}$ and a flame ionization detector (FID) for analysing $\mathrm{CH}_{4}$.

Fluxes were determined using robust linear or nonlinear Hutchinson-Mosier (HMR, Pedersen and others 2010) regressions (R Core Team 2019; Fuß and others 2020). Linear or nonlinear fits were selected according to the kappa.max criterion introduced by Hüppi and others (2018). In brief, the robust linear regression was set as a default. HMR was selected, if the kappa value, that is, the nonlinear shape parameter, did not exceed kappa.max $\left(\mathrm{h}^{-1}\right)$, that is, the quotient of the linear flux estimate and the minimal detectable flux multiplied by the closure time. This was the case for $28 \%$ of $\mathrm{CH}_{4}$ fluxes and $2 \%$ of $\mathrm{N}_{2} \mathrm{O}$ fluxes.

Decreases in $\mathrm{CO}_{2}$ concentration of more than $10 \mathrm{ppm}$ compared to the previous measurement were interpreted as a hint towards a leak of the system or other shortcomings, and the respective data points were discarded. If there were less than four data points per measurement, no flux was calculated. Fluxes indicating an uptake of $\mathrm{CH}_{4}$ higher than $0.5 \mathrm{mg} \mathrm{m}^{-2} \mathrm{~h}^{-1}(n=6)$ were regarded as implausible and discarded (Günther and others 2015; Hütsch 2001). Finally, fluxes of both $\mathrm{CH}_{4}$ and $\mathrm{N}_{2} \mathrm{O}$ were excluded $(n=54)$, if the respective $\mathrm{CO}_{2}$ flux was smaller than $30 \%$ of the maximum $\mathrm{CO}_{2}$ flux of the other two replicates.

\section{Calculation of Annual Balances}

Annual balances of $\mathrm{CH}_{4}$ and $\mathrm{N}_{2} \mathrm{O}$ and uncertainties were estimated using a combination of bootstrap and jackknife procedures (Günther and others 2015). In brief, one of the three replicate flux estimates was randomly selected for each campaign day. This way, 2000 random time series were generated. Out of these data, balances were calculated via linear interpolation, each time omitting one campaign day. The reported annual estimates and uncertainties represent the means of all jackknife balances and standard errors.

\section{Site-specific and Areal Greenhouse Gas Balances}

Methane and $\mathrm{N}_{2} \mathrm{O}$ entered the greenhouse gas balance of sites given their global warming potentials of 28 and 265 t $\mathrm{CO}_{2}$-eq. ha ${ }^{-1} \mathrm{y}^{-1}$ over a timeframe of 100 years (Myhre and others 2013).

$$
\begin{aligned}
& \text { GHG-balance ( } \left.t \mathrm{CO}_{2} \text {-eq. } h a^{-1} y^{-1}\right) \\
& =\mathrm{NEE}+\mathrm{C}_{\text {Export }}+28 \mathrm{CH}_{4}+265 \mathrm{~N}_{2} \mathrm{O}
\end{aligned}
$$

Sphagnum donor material was harvested at MHAR, and the cultivation sites were mowed. The respective $\mathrm{C}$ exports $\left(\mathrm{t} \mathrm{CO}_{2} \mathrm{ha}^{-1} \mathrm{y}^{-1}\right)$ are part of the GHG balance. The C import by Sphagnum fragments and straw was not accounted for as the inoculation took place before starting the measurements, and no straw was present during the measurement period anymore.

In order to derive total areal balances of the three Sphagnum farming sites differing in their irrigation system, emissions of the irrigation system, of dams and of projected biomass harvest have to be included. To do so, we used the following assumptions:

Size of the irrigation polders: The contribution of GHG emitted from the irrigation systems (polders and ditches) was determined by sizing the respective areas using scans of an aerial drone and assuming that the emission of irrigation ditches equals the measured emission of the P-POLDER site. The exact amount of irrigation water could not be determined in Provinzialmoor. Therefore, a theoretical size of 3.8 ha of an irrigation polder needed to balance water deficits of the cultivation area was estimated based on the maximum irrigation amount determined in Drenth $(500 \mathrm{~mm}$ in 2018, Köbbing, personal communication) and a theoretical extractable water column of $0.30 \mathrm{~m}$. 
Peat dams: Peat dams surrounding the cultivation sites were constructed out of the upper layer of onsite peat and will largely decompose to $\mathrm{CO}_{2}$. For D-DITCH, D-DRIP and Provinzialmoor, areas of the surrounding peat dams of $0.17 \mathrm{ha}, 0.17 \mathrm{ha}$ and 0.31 ha were determined using scans of an aerial drone. We assumed that emissions from peat dams correspond to peat extraction sites in North-Western Germany (5.2 t CO $\mathrm{ha}^{-1} \mathrm{y}^{-1}$, Tiemeyer and others 2020).

Re-distribution of Sphagnum fragments: We assumed that all materials harvested at the donor site were spread on the cultivation sites. Therefore, the harvested biomass enters the site-specific GHG balance of M-HAR, but not the areal GHG balances.

Biomass harvest: Over the course of this study, no harvest of Sphagnum biomass was conducted. However, we determined biomass and height of mosses at the cultivation sites (Grobe and others 2021). The linear regression $\left(R^{2}=0.43\right)$ between biomass and height of these data was used to derive biomasses for each measurement site from the height of mosses in our plots. It was further assumed that $70 \%$ of this biomass could be harvested and this estimated extractable biomass was divided by the number of years since the establishment of respective sites and included in the areal GHG balances (t $\mathrm{CO}_{2}$-eq. ha ${ }^{-1} \mathrm{y}^{-1}$, Table 4). Areal GHG balances of the different irrigation systems were finally standardized per unit of estimated extractable Sphagnum biomass (t DM ha ${ }^{-1} \mathrm{y}^{-1}$, Table 4).

\section{Results \\ Hydro-meteorological Conditions}

The early summer of 2017 was unusually dry but extensive rainfalls in the second half of the year resulted in an annual precipitation of $50 \mathrm{~mm}$ above the long-term average value of $791 \mathrm{~mm}$ in Lingen (German Weather Service). However, in 2018, only $561 \mathrm{~mm}$ was measured, which was the lowest value since 1960 . With $10.9^{\circ} \mathrm{C}$ and $11.7^{\circ} \mathrm{C}$, both years were warmer than the long-term average of $9.8^{\circ} \mathrm{C}$. 2018 was the second warmest year since recording began in 1951 .

WTD at the near-natural reference site (M-NAT) was close to the peat surface throughout both measurement years, with annual means of $-0.05 \pm$ $0.03 \mathrm{~m}$ (mean of daily averages \pm standard deviation) in 2017 and $-0.07 \pm 0.06 \mathrm{~m}$ in 2018 (Fig. 2A). Even in summer 2018, WTD did not fall below $-0.16 \mathrm{~m}$. At the ditch irrigation site (D-DITCH),$-0.12 \pm 0.13 \mathrm{~m}$ and $-0.14 \pm 0.13 \mathrm{~m}$ were measured in 2017 and 2018 . As this monitoring well temporarily fell dry in June and July 2018, the true mean of site D-DITCH might be slightly lower. At the drip irrigation site (D-DRIP), annual mean WTDs were $-0.09 \pm 0.12 \mathrm{~m}$ and $-0.12 \pm$ $0.12 \mathrm{~m}$, in Provinzialmoor (mean of sites P-PAL, PPAP and P-MIX), $-0.11 \pm 0.11 \mathrm{~m}$ and $-0.25 \pm$ $0.22 \mathrm{~m}$. WTDs at all cultivation sites fluctuated strongly and fell below $-0.30 \mathrm{~m}$ for 51 and 81 days in 2017 and 2018 at D-DITCH, for 39 and 42 days at D-DRIP and for 31 and 135 days in Provinzialmoor. During summer 2018, WTDs in Provinzialmoor even fell below $-0.60 \mathrm{~m}$, while water management in Drenth could be largely maintained.

While the incomplete data of 2017 already suggested a lower WFPS in Provinzialmoor, WFPS was considerably higher in D-DRIP $(83 \pm 12 \%)$ than in P-MIX $(66 \pm 19 \%)$, but still lower than in M-NAT $(93 \pm 4 \%)$ in 2018 (Fig. 2B). In 2018, WFPS tended to be higher at same WTDs in D-DRIP compared to P-MIX. Humidity near the soil surface was measured in 2018 only and was $79 \pm 23 \%$ at MNAT (mean \pm standard deviation), $80 \pm 21 \%$ at DDRIP and $78 \pm 22 \%$ at P-MIX.

\section{Water Quality}

Values of $\mathrm{pH}$ and EC as well as solute concentrations were low at the near-natural and at the cultivation sites (Table 2). The irrigation water in Drenth showed high $\mathrm{pH}$ values and concentrations of $\mathrm{Ca}^{2+}$, especially when ground water was added in dry summer months. However, concentrations of soil pore water at the plots were hardly affected. Maximum pH was 8.7 in the pond water and 5.7 at the measurement plots, and the maximum concentrations of $\mathrm{Ca}^{2+}$ were $33.9 \mathrm{mg} \mathrm{l}^{-1}$ and $15.9 \mathrm{mg} \mathrm{l}^{-1}$, respectively. At D-DITCH, a peak of $\mathrm{NO}_{3}{ }^{-}$concentrations (up to $42.6 \mathrm{mg} \mathrm{l}^{-1}$ in comparison with the overall mean of $4.1 \mathrm{mg} \mathrm{l}^{-1}$ ) was measured in the first summer.

\section{Vegetation Development}

The harvested plots in the near-natural area recovered quickly (Fig. 3). In two of the replicate plots, plant cover and species composition resembled the reference plots already one year after harvesting. However, at one replicate plot (MHAR.2), remaining mosses were drowned and died off in the subsequent winter. At the cultivation sites, the Sphagnum cover increased during the course of this study and spots of bare peat largely closed. However, vegetation developed unequally at the different irrigation treatments (Fig. 3). The mean Sphagnum cover at the cultivation sites de- 

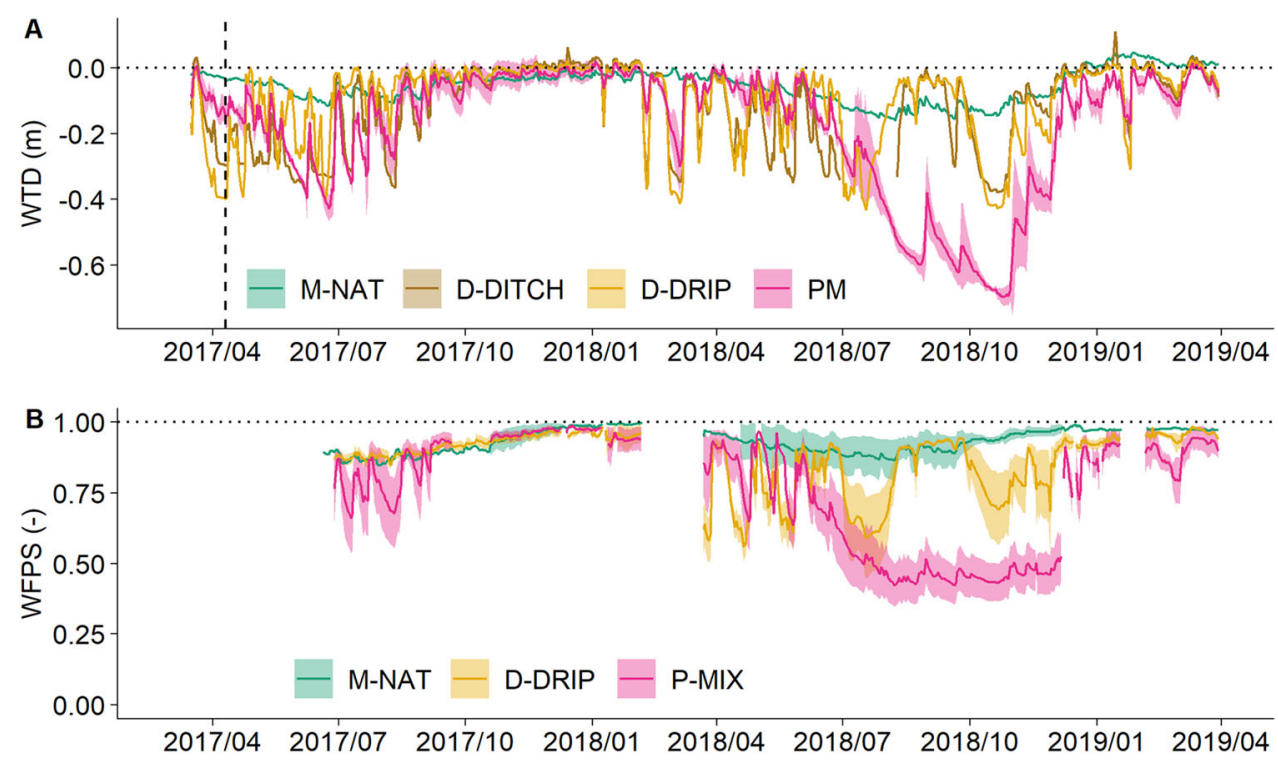

Figure 2. A Water table depths (WTD) of the near-natural site (M-NAT) and the different irrigation systems ditch irrigation (D-DITCH), drip irrigation (D-DRIP) and a combination of ditch irrigation and previous re-wetting (PM, mean and standard deviation of sites P-PAL, P-PAP and P-MIX); and B water-filled pore spaces (WFPS) of the upper centimetres of M-NAT, D-DRIP and P-MIX. The vertical dashed line denotes the change from subsurface drain pipes to aboveground drip irrigation at D-DRIP. In June and July 2018, WTD of site D-DITCH fell below detection limit and is therefore not plotted.

creased during the dry summer 2018, but mosses slightly recovered until spring 2019. At site DDITCH, mean Sphagnum cover decreased throughout the study period. The cover of vascular plants was higher at P-PAL, P-PAP and P-MIX compared to D-DITCH and D-DRIP. Plant species known to play an important role in peatland $\mathrm{CH}_{4}$ exchange also increased in abundance, especially the cover of Eriophorum species increased from 2017 to 2018 at the cultivation sites. Rhynchospora alba cover increased in 2018 at the near-natural site and also slightly at the cultivation sites. Molinia caerulea was mainly observed at the near-natural sites and at PMIX and covers decreased in 2018. At P-PAP and PPAL, higher covers of Erica tetralix and Calluna vulgaris were recorded which increased in 2018.

\section{Carbon Dioxide}

NEE of the near-natural sites was negative (net uptake) in 2017 and positive in 2018 (Table 3). Of the cultivation sites, highest $\mathrm{CO}_{2}$ emissions were determined at D-DITCH, followed by D-DRIP and the sites in Provinzialmoor. P-PAP showed the highest GPP, in its size almost comparable to the near-natural sites, and acted as a $\mathrm{CO}_{2}$ sink in 2017. Lowest GPPs were measured at D-DITCH. Fluxes of both $R_{\text {eco }}$ and GPP were higher at the Provinzialmoor sites compared to the Drenth sites. At the cultivation sites, the extraordinary hot and dry summer 2018 resulted in an earlier GPP peak compared to 2017 (Fig. 4). At D-DITCH, GPP even shrank to half during July and August before it increased again in September. This decrease in GPP was considerably less pronounced at the near-natural sites and at D-DRIP. $\mathrm{CO}_{2}$ emissions increased with decreasing WTDs at all sites with the exception of D-DRIP (Fig. 5A), as $R_{\text {eco }}$ increased in 2018 to a greater extent than the respective GPP values. However, mean WTD only explained changes in NEE between years as in 2018, NEEs of P-MIX and D-DITCH were similar despite different annual mean WTDs and in 2017, similar mean WTDs resulted in different NEEs at the cultivation sites.

\section{Methane}

Highest $\mathrm{CH}_{4}$ emissions were measured at the nearnatural sites and decreased in 2018 (Fig. 5B, Table 3). Harvested plots (M-HAR) emitted more $\mathrm{CH}_{4}$, about $20 \%$ in 2017 and $10 \%$ in 2018 . From the irrigation polder in Provinzialmoor (P-POLDER), roughly a third of the amount of M-NAT, that is, 6.9 and $8.9 \mathrm{~g} \mathrm{CH}_{4}-\mathrm{C} \mathrm{m} \mathrm{m}^{-2} \mathrm{y}^{-1}$, was released (Table 3). At our and other Sphagnum farming sites (Beyer and Höper 2015; Günther and others 2017), low $\mathrm{CH}_{4}$ emissions were found. However, $\mathrm{CH}_{4}$ emissions of the cultivation sites increased in 2018 despite lower WTDs. This increase coincided with an increase of Eriophorum cover (E. angustifolium 
and E. vaginatum, Fig. 6A). Campaign $\mathrm{CH}_{4}$ fluxes also correlated with daily mean soil temperatures (Fig. 6B and C).

\section{Nitrous Oxide}

With the notable exception of D-DITCH, $\mathrm{N}_{2} \mathrm{O}$ emissions were low at all sites (Table 3). In general, high annual $\mathrm{N}_{2} \mathrm{O}$ emissions coincided with low vegetation covers (Fig. 7A). The high emissions of D-DITCH could mainly be attributed to a shortterm peak in summer 2017 and coincided with a rising WTD after a dry period and high concentrations of $\mathrm{NO}_{3}{ }^{-}$in the soil water (Fig. 7B and C). The $\mathrm{NO}_{3}{ }^{-}$did not seem to originate from the irrigation water, as no elevated concentrations were measured in the irrigation ponds.

\section{Site-specific and Areal Greenhouse Gas Balances}

The GHG balances of the near-natural sites (MNAT, M-HAR) were characterized by high $\mathrm{CH}_{4}$ emissions, but M-NAT was still accumulating $\mathrm{C}$ in 2017 (Table 3). At M-HAR, the amount of harvested biomass equals an export of $9.1 \mathrm{t} \mathrm{CO}_{2}^{-}$ eq. ha ${ }^{-1} \mathrm{y}^{-1}$. In contrast, NEE dominated the GHG balances of the cultivation sites. The only net GHG uptake was calculated for site P-PAP in 2017. High $\mathrm{CO}_{2}$ and $\mathrm{N}_{2} \mathrm{O}$ emissions contributed to the balance of D-DITCH. The GHG balance of the irrigation polder in Provinzialmoor (P-POLDER) was composed of $\mathrm{CH}_{4}$ and $\mathrm{CO}_{2}$ emissions, the mean of both years was $6.5 \mathrm{t} \mathrm{CO}_{2}$-eq. $\mathrm{ha}^{-1} \mathrm{y}^{-1}$. The C-export generated by mowing of vascular plants at the cultivation sites added up to only 0.13 and $0.05 \mathrm{t}$ $\mathrm{CO}_{2}$-eq. ha ${ }^{-1} \mathrm{y}^{-1}$ for Provinzialmoor and Drenth, respectively, and is therefore not visible in Fig. 8 but included in Table 4 .

In accordance with the different vegetation development, the three irrigation systems produced distinct GHG balances. Mean site-specific GHG balances were highest in D-DITCH, followed by DDRIP and Provinzialmoor (mean of sites P-PAL, PPAP and P-MIX, Table 4). Including emissions of irrigation systems and dams, drip irrigation (DDRIP) generated the smallest areal GHG balance, whereas irrigation by ditches combined with previous re-wetting (Provinzialmoor) produced the lowest GHG emissions per ton of Sphagnum biomass.

\section{Discussion}

\section{Sphagnum Farming on Highly Decomposed Peat}

In this study, we provide evidence for the general feasibility of large-scale Sphagnum farming on highly decomposed peat remaining after peat extraction. Further, results are not only relevant for post-extraction sites, as agriculturally used bog peats may have also already lost the upper horizons due to mineralization and share similar physical soil characteristics. In Germany, this applies to more than half of the total bog area.

However, the highly decomposed peat challenges a successful cultivation of peat mosses. Measured $\mathrm{K}_{\mathrm{s}}$ values were small compared to the $1.13 \mathrm{~m} \mathrm{~d}^{-1}$ reported for a nearby Sphagnum farming project on less decomposed peat (Brust and others 2018), and $\mathrm{BD}$ was slightly higher compared to the range of $0.07-0.12 \mathrm{~g} \mathrm{~cm}^{3}$ reported for another nearby site (Gaudig and others 2017). Over prolonged periods, WTDs at the cultivation sites fell far below the

Table 2. Values of $\mathrm{pH}$ and Electric Conductivity (EC) as well as Solute (DOC $=$ dissolved organic carbon, $\mathrm{NO}_{3}{ }^{-}=$nitrate, $\mathrm{NH}_{4}^{+}=$ammonium, $\mathrm{PO}_{4}{ }^{3-}=$ phosphate, $\mathrm{SO}_{4}{ }^{2-}=$ sulphate, $\mathrm{Ca}^{2+}=$ calcium) Concentrations $\left(\mathrm{mg} \mathrm{l}^{-1}\right)$ of Irrigation Water and of Soil Water at the Measurement Sites (means of biweekly sampling campaigns \pm standard deviation)

\begin{tabular}{lcccccc}
\hline & $\begin{array}{c}\text { Meerkolk } \\
\text { Mean of sites }\end{array}$ & $\begin{array}{c}\text { Drenth } \\
\text { Irrigation ponds }\end{array}$ & $\begin{array}{c}\text { Drenth } \\
\text { D-DITCH }\end{array}$ & $\begin{array}{c}\text { Drenth } \\
\text { D-DRIP }\end{array}$ & $\begin{array}{c}\text { Provinzialmoor } \\
\text { Irrigation polder }\end{array}$ & $\begin{array}{c}\text { Provinzialmoor } \\
\text { Mean of sites }\end{array}$ \\
\hline $\mathrm{pH}$ & $4.6 \pm 0.4$ & $5.5 \pm 1.3$ & $4.4 \pm 0.4$ & $4.3 \pm 0.3$ & $4.2 \pm 0.3$ & $4.4 \pm 0.3$ \\
$\mathrm{EC}$ & $54 \pm 16$ & $152 \pm 59$ & $159 \pm 53$ & $121 \pm 23$ & $93 \pm 30$ & $117 \pm 30$ \\
$\mathrm{DOC}$ & $31 \pm 13$ & $51 \pm 20$ & $68 \pm 20$ & $70 \pm 22$ & $43 \pm 19$ & $59 \pm 26$ \\
$\mathrm{NO}_{3}{ }^{-}$ & $0.1 \pm 0.1$ & $4.0 \pm 4.3$ & $4.1 \pm 8.4$ & $0.4 \pm 0.4$ & $0.3 \pm 0.2$ & $0.3 \pm 1.0$ \\
$\mathrm{NH}_{4}{ }^{+}$ & $0.5 \pm 0.3$ & $0.8 \pm 0.7$ & $5.2 \pm 2.0$ & $1.4 \pm 1.2$ & $0.8 \pm 0.7$ & $1.9 \pm 1.3$ \\
$\mathrm{PO}_{4}{ }^{3-}$ & $0.02 \pm 0.05$ & $0.07 \pm 0.12$ & $0.01 \pm 0.02$ & $0.06 \pm 0.09$ & $0.02 \pm 0.06$ & $0.07 \pm 0.19$ \\
$\mathrm{SO}_{4}{ }^{2-}$ & $0.6 \pm 0.3$ & $11.4 \pm 0.4$ & $7.4 \pm 3.9$ & $4.9 \pm 3.0$ & $1.3 \pm 0.7$ & $3.8 \pm 3.0$ \\
$\mathrm{Ca}^{2+}$ & $0.5 \pm 0.6$ & $9.7 \pm 8.9$ & $2.3 \pm 3.4$ & $2.6 \pm 3.0$ & $0.6 \pm 1.7$ & $1.3 \pm 2.1$ \\
& & & & & & \\
\hline
\end{tabular}




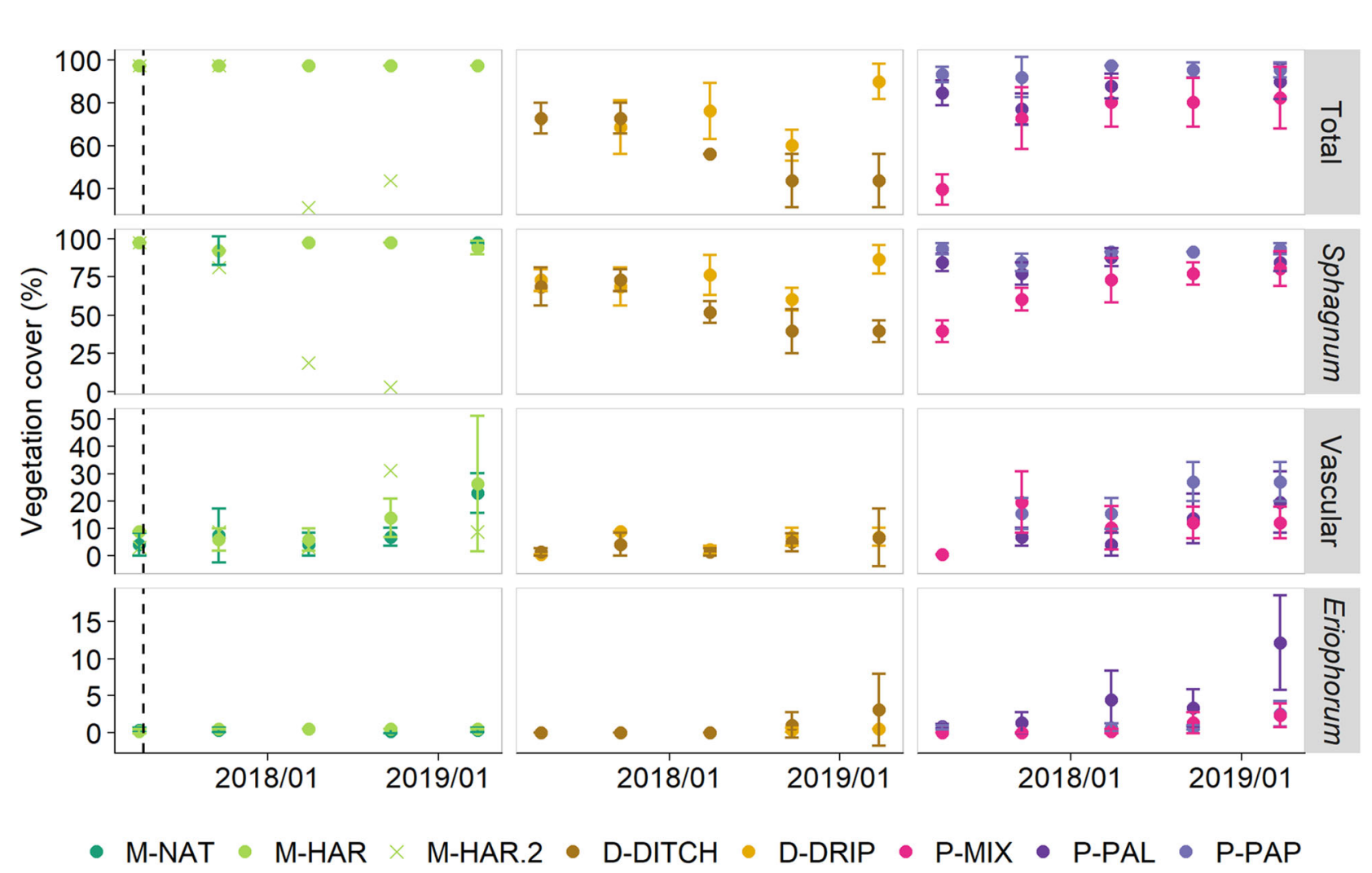

Figure 3. Covers of peat mosses and vascular plants (mean and standard deviations of replicate plots) at the near-natural sites (M-NAT and M-HAR) and at the cultivation sites. One harvested plot (M-HAR.2) did not recover and covers of total vegetation and Sphagnum could not be determined in March 2019. Eriophorum cover is the sum of E. angustifolium and E. vaginatum covers, though E. angustifolium covers were dominant. The dashed vertical line denotes the date of harvest at $M$ HAR.

targeted range close to the surface. Price and Whitehead (2001) observed Sphagnum recolonization of an abandoned block-cut bog at mean WTD of $-0.25 \pm 0.14 \mathrm{~m}$ and volumetric water contents higher than $50 \%$. WTDs measured at our cultivation sites were higher, but WFPS temporarily dropped below 50\% (corresponding to volumetric water contents lower than 50\%) in 2018, especially at P-MIX. During these periods of hydrological stress, mosses lost their green colour and became visibly inactive.

Although mosses recovered and covers increased again in early 2019, the 2018 drought affected biomass production. The estimated Sphagnum biomass in March 2019 was $1.2 \mathrm{t}$ dry mass per hectare at D-DITCH (41 months since inoculation), $2.1 \mathrm{t}$ at D-DRIP (41 months), $3.3 \mathrm{t}$ at P-PAP (41 months) and $2.5 \mathrm{t}$ at P-PAL (36 months) and P-MIX (29 months). A detailed analysis of Sphagnum establishment at our sites is available in Grobe and others (2021), while our data are restricted to the GHG plots only. Biomass production in Drenth was low, but values of the sites in Provinzialmoor are comparable to a neighbouring Sphagnum farming project $\left(1.0 \mathrm{t} \mathrm{ha}^{-1} \mathrm{y}^{-1}\right.$ in the first 3 years, Gaudig and others 2017). In a greenhouse experiment, Gaudig and others (2020) found that peat moss productivities can reach up to $7 \mathrm{tha}^{-1} \mathrm{y}^{-1}$ for $S$. papillosum at a constant WTD $0.02 \mathrm{~m}$ below capitulum.

Vascular plants also colonized the cultivation sites and higher Sphagnum covers coincided with higher covers of vascular plants (Grobe and others 2021). This supports the findings of McNeil and Waddington (2003), who observed that vascular plants promote Sphagnum growth by providing shadow and suitable moistures, a mechanism especially useful during hydrological stress (Buttler and others 1998) and after cutting of mosses (Krebs and others 2018). Vascular plants generally profited from the dry conditions in 2018 and shaded peat mosses remained active longer at the beginning of dry periods compared to spots without shading. 


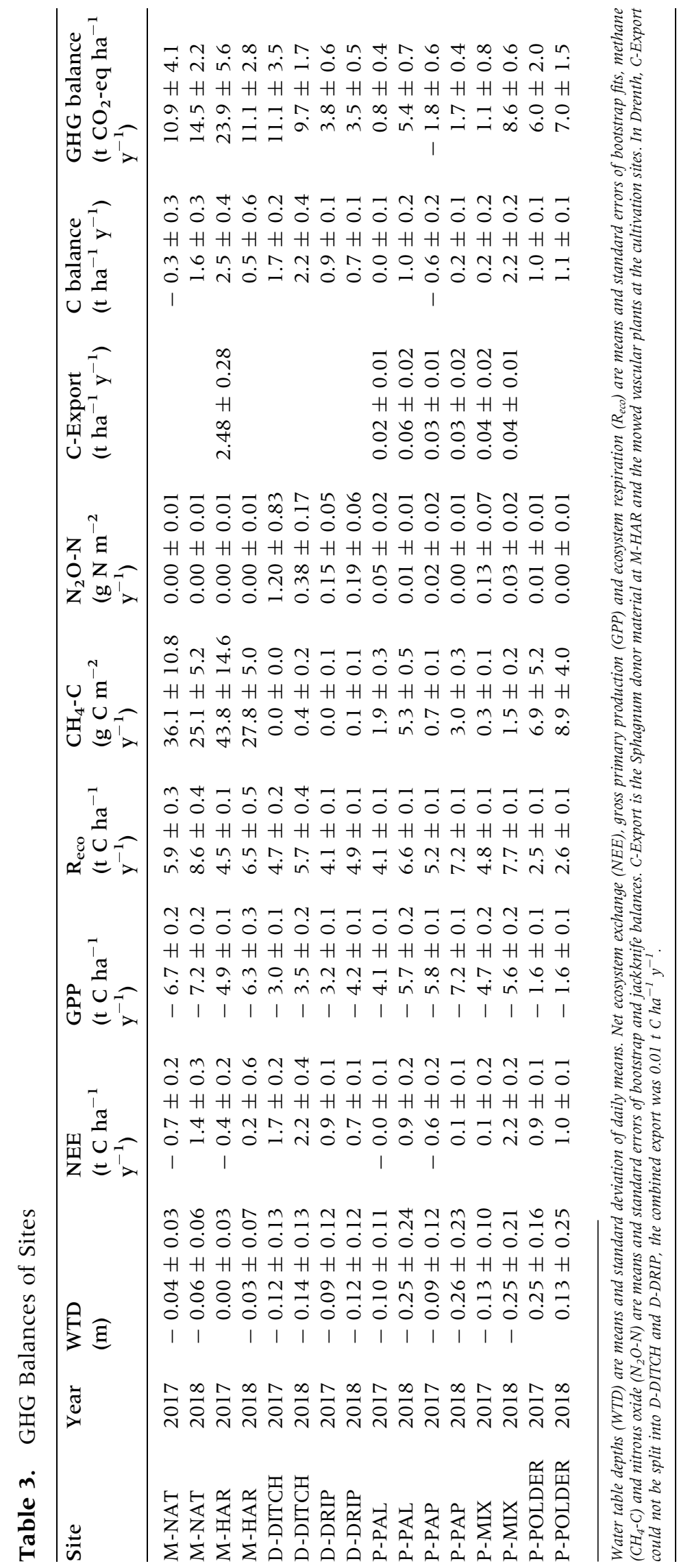




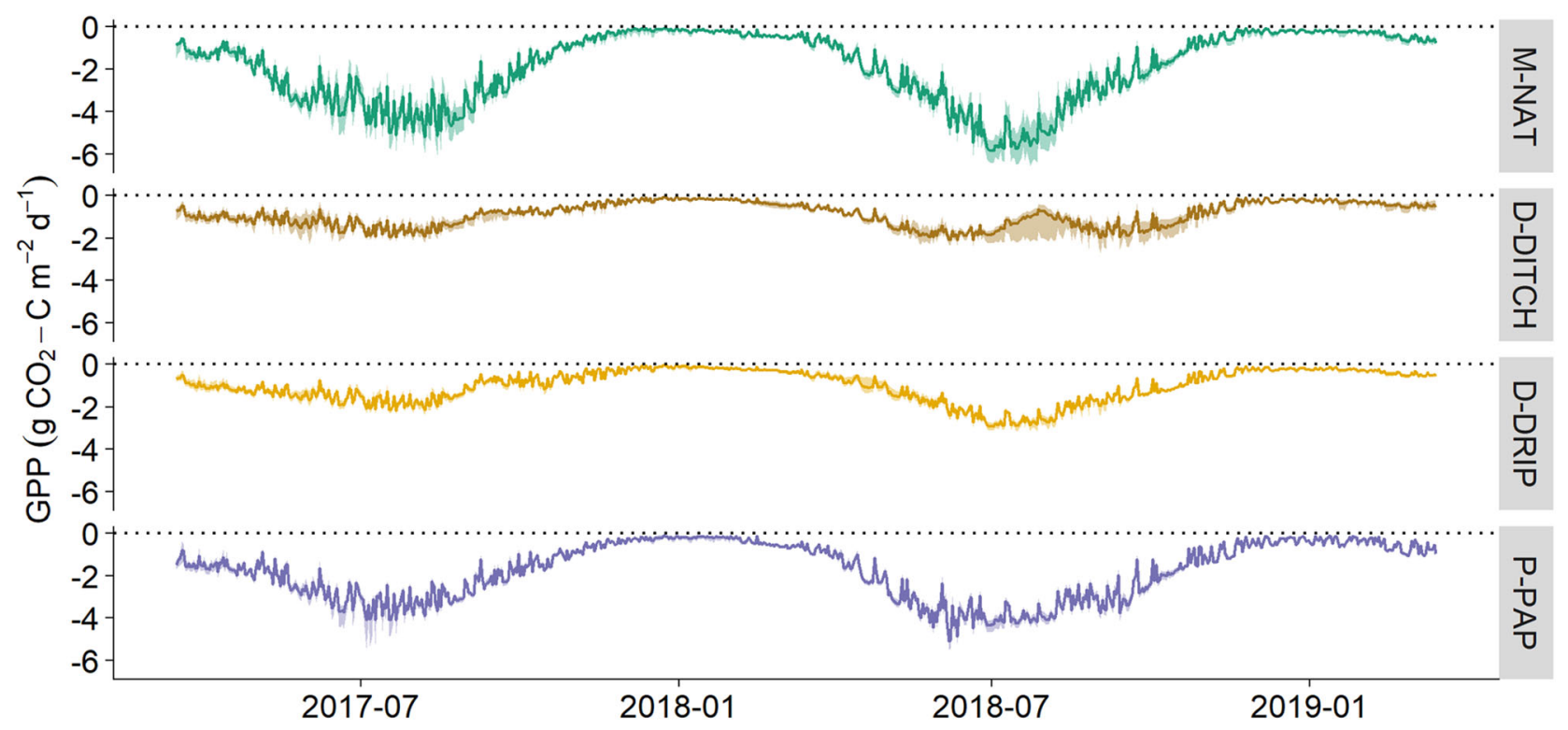

Figure 4. Daily values of gross primary production (GPP) in 2017 and 2018 at the near-natural site (M-NAT) and at the cultivation sites $(\mathrm{D}-\mathrm{DITCH}=$ ditch irrigation, $\mathrm{D}$-DRIP $=$ drip irrigation, P-PAP (exemplary for Provinzialmoor $)=$ ditch irrigation combined with previous re-wetting).

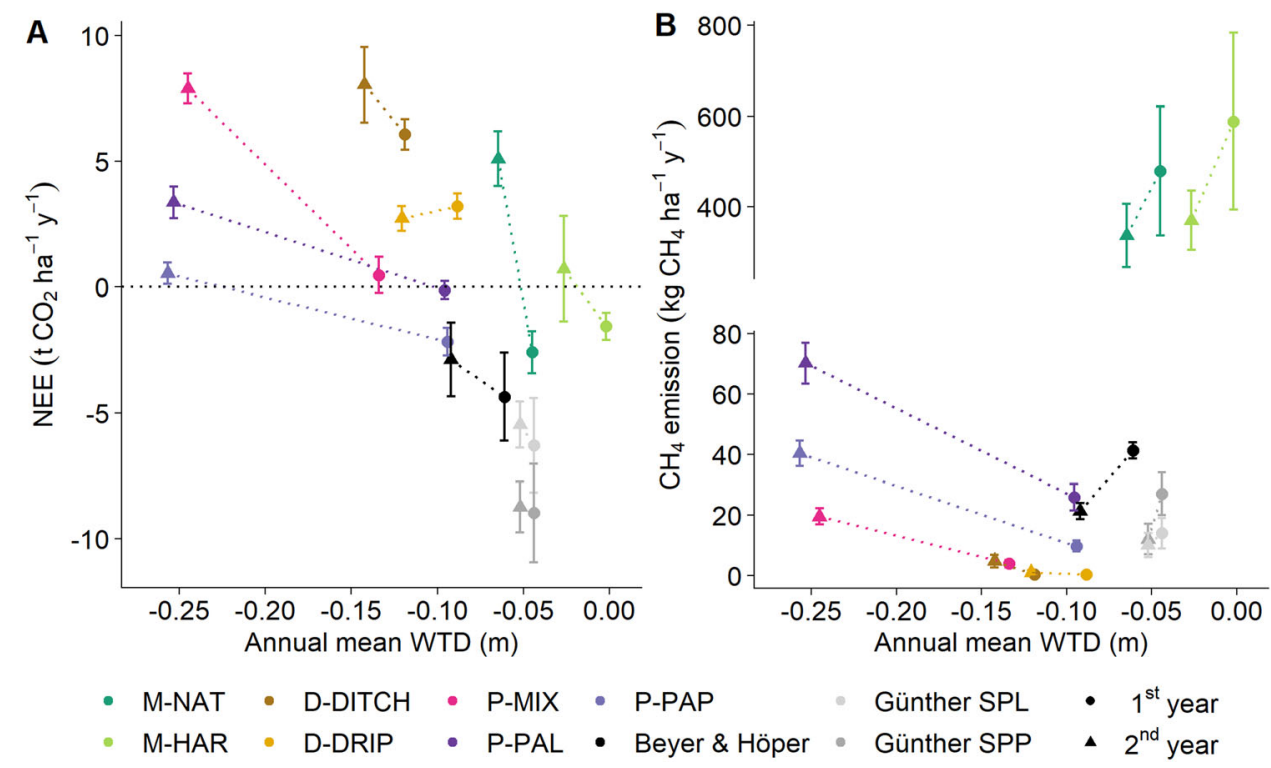

Figure 5. A Net ecosystem exchange (NEE) and annual mean water table depths (WTD); and $\mathbf{B}$ methane $\left(\mathrm{CH}_{4}\right)$ emission and WTD. First and second years are 2017 and 2018 at our sites, 2010 and 2011 (that is, 6 and 7 years after establishment) in Beyer and Höper (2015) and 2012 and 2013 (that is, first and second years after establishment) in Günther and others (2017; SPL = Sphagnum palustre, SPP = Sphagnum papillosum). Dotted lines combine both measurement years of each site.

\section{Drivers of GHG Exchange}

Carbon Dioxide $\left(\mathrm{CO}_{2}\right)$

WTD affected the $\mathrm{CO}_{2}$ exchange of all sites. At the near-natural site, differences in WTD of only a few centimetres shifted M-NAT from a sink of $\mathrm{CO}_{2}$ comparable to other near-natural bogs $(-2.4 \pm$ $1.2 \mathrm{t} \mathrm{CO}_{2} \mathrm{ha}^{-1} \mathrm{y}^{-1}$, Helfter and others 2015) to a considerable source in 2018. The effect of the dry year 2018 on mean WTDs and the accompanying increased $\mathrm{CO}_{2}$ emissions were particularly pronounced in Provinzialmoor. Fluctuations of WTDs 


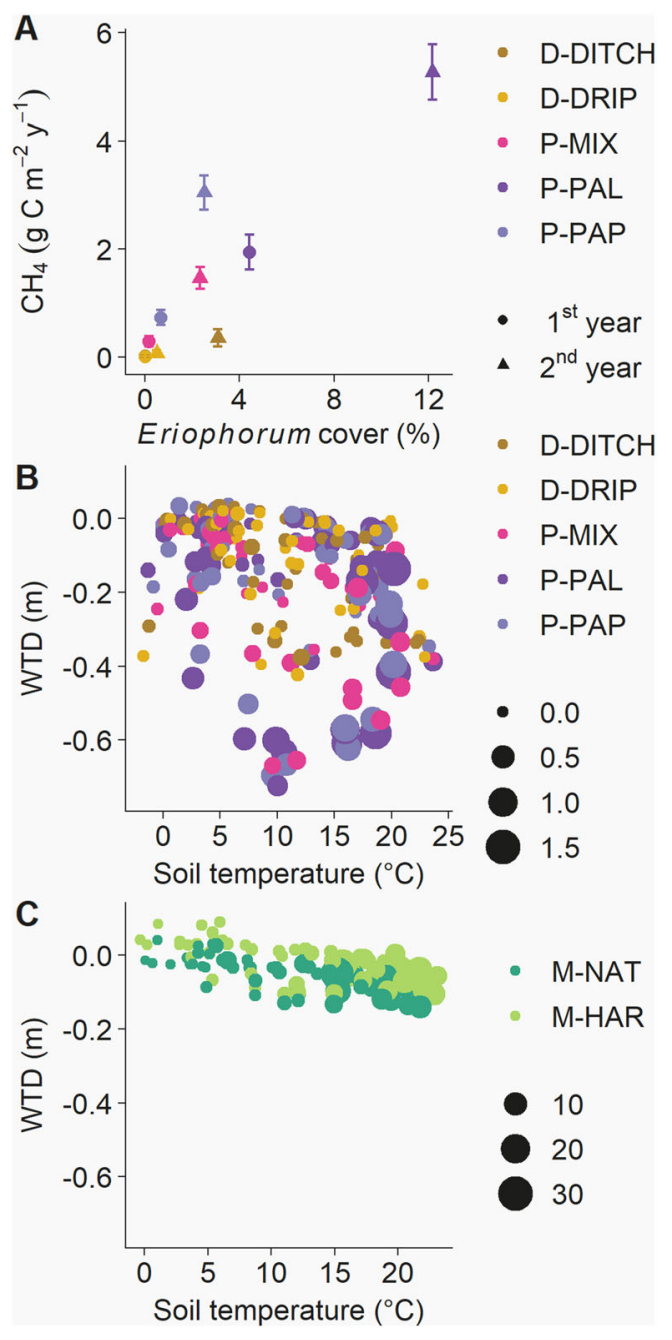

Figure 6. A Methane $\left(\mathrm{CH}_{4}\right)$ emissions and covers of Eriophorum (E. angustifolium and E. vaginatum) at the end of measurement years; $\mathbf{B}$ campaign $\mathrm{CH}_{4}$ fluxes $\left(\mathrm{mg} \mathrm{CH}_{4}\right.$ $\mathrm{C} \mathrm{m}^{-2} \mathrm{~h}^{-1}$ ) and the respective daily mean soil temperatures and water table depths (WTD) at the cultivation sites and $\mathbf{C}$ at the near-natural sites.

will affect NEEs of Sphagnum farming sites, especially when mosses are exposed to periodical desiccation. In a laboratory experiment, McNeil and Waddington (2003) found that respiration of peat columns grown with Sphagnum increased shortly after drying and subsequent re-wetting, while GPP recovered only after three weeks of water saturation, highlighting the importance of stable WTDs. Brown and others (2017) also found that water table fluctuation best predicted NEE and that a stable WTD lead to greater uptake of $\mathrm{CO}_{2}$.

In addition to the hydrology of the sites, the development of the vegetation cover influenced NEE. Lower GPP values at D-DRIP and D-DITCH were consistent with the poor vegetation development, while the decrease of NEE at D-DRIP in 2018 could be explained by an increase in vegetation cover. At sites P-PAP and P-PAL, the restoration of the sites as sinks of atmospheric $\mathrm{CO}_{2}$ in 2017 can be attributed to the almost completely closed Sphagnum lawn. Site P-PAP also showed the highest vascular plant cover of all cultivation sites. In general, higher vascular plant covers went along with increased GPP and $R_{\text {eco }}$ fluxes.

In line with peatlands restored with the moss layer transfer technique (Nugent and others 2018), the time needed for a Sphagnum farming site to become a sink of atmospheric $\mathrm{CO}_{2}$ cannot easily be predicted. Comparing our results to previous neighbouring Sphagnum farming experiments (Beyer and Höper 2015; Günther and others 2017) showed no clear correlation of NEE and GPP with the age of sites, and differences in $\mathrm{CO}_{2}$ exchange are probably rather explained by the high and stable WTD in those two studies (Fig. 5A). In addition, dry years can also turn older restored sites into sources of $\mathrm{CO}_{2}$ (Strack and others 2009; Wilson and others 2016b). Both GPP and $R_{\text {eco }}$ values increased from 2017 to 2018 . GPP was influenced by growing vegetation covers, while lower WTDs and higher temperatures affected $R_{\text {eco. }}$ A higher biomass probably also contributed to the higher $R_{\text {eco, }}$ but still the increase in $R_{\text {eco }}$ was more than offsetting GPP increases. Possibly, the growing vegetation would have turned the cultivation areas in sinks of atmospheric $\mathrm{CO}_{2}$ in 2018 under the condition of sufficient water supply. The development of daily GPP values indicates that GPP was strongly affected by the 2018 drought, above all at D-DITCH (Fig. 4).

\section{Methane $\left(\mathrm{CH}_{4}\right)$}

The $\mathrm{CH}_{4}$ emissions of the near-natural site were high compared to the emission factors for re-wetted and near-natural bogs (Wilson and others 2016a) or temperate wetlands (Turetsky and others 2014). In addition to the shallow WTD, reasons could be relatively high temperatures compared to both long-term average and other studies summarized by those reviews, the cover of vascular plants or the

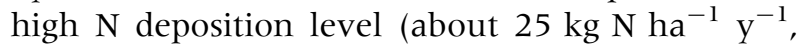
Hurkuck and others 2016). Meerkolk is surrounded by intensively used agricultural area, which might influence GHG exchange. In a fertilization experiment, Juutinen and others (2018) could associate increasing $\mathrm{CH}_{4}$ fluxes with higher $\mathrm{N}$ input in a temperate bog. Compared to semi-natural sites in a similar climatic setting, our values are not 

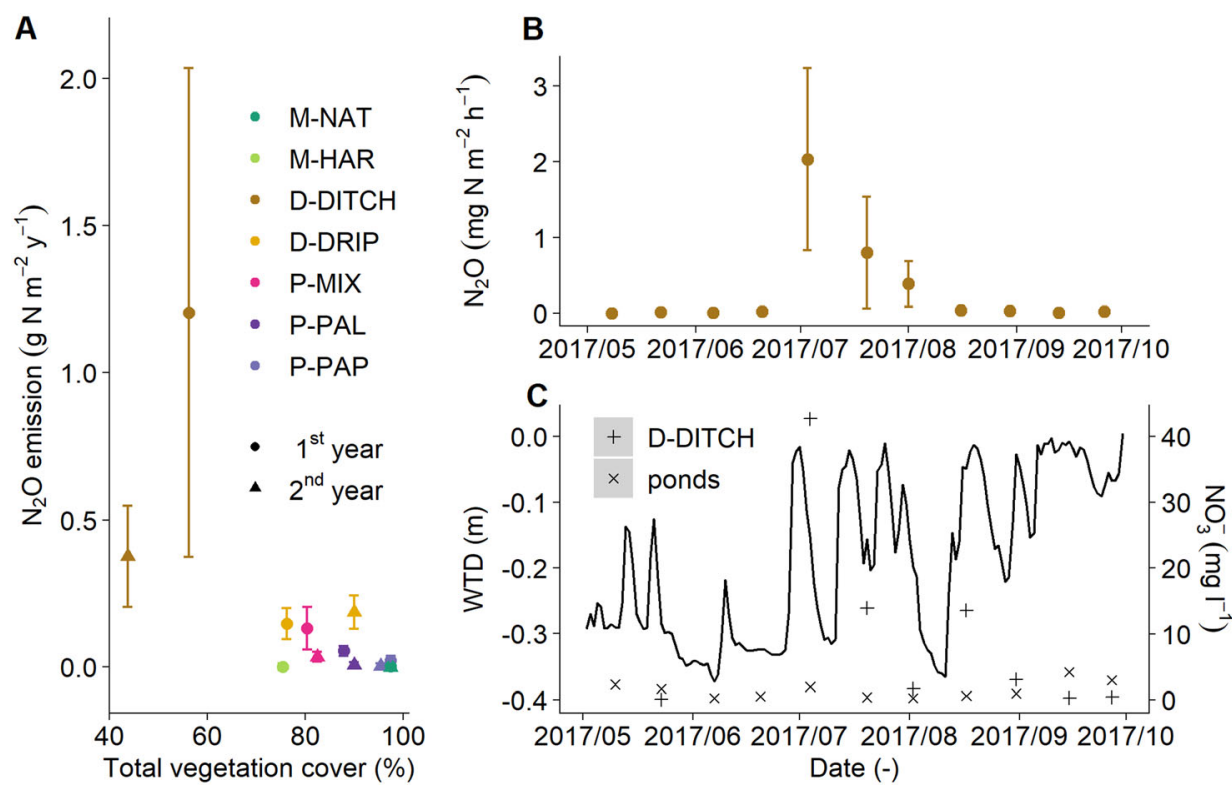

Figure 7. A Annual nitrous oxide $\left(\mathrm{N}_{2} \mathrm{O}\right)$ emissions (mean of jackknife balances \pm standard error) and total vegetation covers; B campaigns with peak $\mathrm{N}_{2} \mathrm{O}$ fluxes at site D-DITCH (mean of replicates \pm standard deviation); and $\mathbf{C}$ the respective water table depths (WTD) and nitrate $\left(\mathrm{NO}_{3}{ }^{-}\right)$concentrations of the irrigation ponds (ponds) and of the soil water at the measurement plots (D-DITCH)

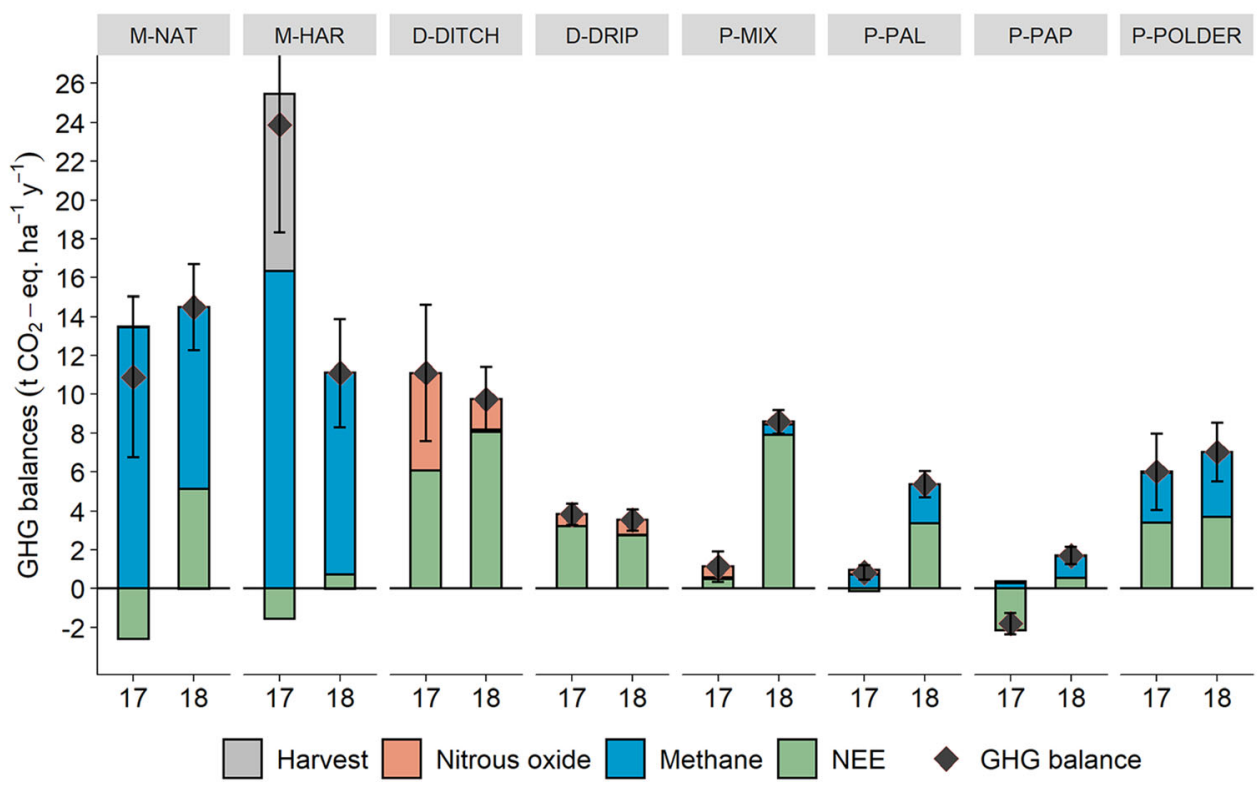

Figure 8. Annual exchange of nitrous oxide, methane and carbon dioxide (NEE) and site-specific GHG balances of the near-natural sites $(\mathrm{M}-\mathrm{NAT}=$ reference, $\mathrm{M}-\mathrm{HAR}=$ harvest of Sphagnum donor material), of the cultivation sites (D$\mathrm{DITCH}=$ ditch irrigation, $\mathrm{D}$-DRIP $=$ drip irrigation, $\mathrm{P}-\mathrm{MIX}, \mathrm{P}-\mathrm{PAL}$ and $\mathrm{P}-\mathrm{PAP}=$ ditch irrigation combined with previous rewetting) and of the irrigation polder in Provinzialmoor (P-POLDER).

implausible: Drösler (2005) measured $38 \mathrm{~g} \mathrm{CH}_{4}$-C $\mathrm{m}^{2} \mathrm{y}^{-1}$ in a semi-natural peatland in Bavaria dominated by Sphagnum cuspidatum, Scheuchzeria palustris and Rhynchospora alba, whereas 5-14 g $\mathrm{CH}_{4}-\mathrm{C} \mathrm{m}^{2} \mathrm{y}^{-1}$ were reported for a near-natural bog dominated by Sphagnum fallax in North-Western Germany (Tiemeyer and others 2020).

In general, campaign $\mathrm{CH}_{4}$ fluxes increased with increasing daily mean soil temperatures and highest fluxes were measured at WTDs close to the peat 
Table 4. Areal GHG Balances of Irrigation Systems $(\mathrm{D}-\mathrm{DITCH}=$ ditch irrigation, D-DRIP $=$ drip irrigation, Provinzialmoor $=$ ditch irrigation combined with previous re-wetting, that is, mean of sites P-PAL, P-PAP and P-MIX) and Product-related GHG Balances per Ton of Extractable Sphagnum Biomass

\begin{tabular}{|c|c|c|c|}
\hline $\begin{array}{l}\text { Drenth } \\
\text { D-DITCH }\end{array}$ & $\begin{array}{l}\text { Drenth } \\
\text { D-DRIP }\end{array}$ & Provinzialmoor & \\
\hline 10.4 & 3.7 & 2.6 & Mean site-specific GHG balance of cultivation sites ( $\mathrm{C} \mathrm{CO}_{2}$-eq. $\mathrm{ha}^{-1} \mathrm{y}^{-1}$ ) \\
\hline 6.5 & 6.5 & 6.5 & GHG balance of polders and ditches (t $\mathrm{CO}_{2}$-eq. $\mathrm{ha}^{-1} \mathrm{y}^{-1}$ ) (site P-POLDER) \\
\hline 5.2 & 5.2 & 5.2 & GHG balance of dams (t CO 2 -eq. ha ${ }^{-1} \mathrm{y}^{-1}$ ) (Tiemeyer and others 2020) \\
\hline $5: 1$ & $10: 1$ & $0.6: 1$ & Ratio cultivation area/irrigation area \\
\hline $2.2: 1$ & $2.4: 1$ & $7.4: 1$ & Ratio cultivation area/dams \\
\hline 0.05 & 0.05 & 0.13 & Extracted biomass (mowing) (t $\mathrm{CO}_{2}$-eq. $\mathrm{ha}^{-1} \mathrm{y}^{-1}$ ) \\
\hline 0.5 & 0.9 & 1.4 & $\begin{array}{l}\text { Estimated extractable biomass (vascular plants }+ \text { Sphagnum) }\left(\mathrm{t} \mathrm{CO}_{2} \text {-eq. ha }{ }^{-1}\right. \\
\left.\mathrm{y}^{-1}\right)\end{array}$ \\
\hline 8.9 & 5.3 & 6.6 & Areal GHG balance of irrigation system ( $\mathrm{t} \mathrm{CO}_{2}$-eq. ha ${ }^{-1} \mathrm{y}^{-1}$ ) \\
\hline 0.3 & 0.4 & 0.7 & Estimated extractable Sphagnum biomass (t DM ha-1 $\left.\mathrm{y}^{-1}\right)$ \\
\hline 29.5 & 13.2 & 9.4 & GHG balance per extractable ton of Sphagnum biomass (t $\mathrm{CO}_{2}$-eq. $\mathrm{t} \mathrm{DM}^{-1}$ ) \\
\hline
\end{tabular}

surface. However, high emissions were observed at the cultivation sites during drought in 2018, which could be attributed to the vegetation composition of the plots. Specialized wetland plants possessing aerenchymous tissues enable a plant-mediated transport of gases between soil and atmosphere (Gray and others 2013). At the cultivation sites, increasing covers of Eriophorum angustifolium and Eriophorum vaginatum from 2017 to 2018 resulted in higher $\mathrm{CH}_{4}$ emissions (Fig. 6A) despite drier conditions, a pattern already described in previous studies (Greenup and others 2000; Tuittilla and others 2000; Waddington and Day 2007). Molinia caerulea (Leroy and others 2019; Vanselow-Algan and others 2015; Rigney and others 2018) and Juncus effusus (Henneberg and others 2015) have also been associated with higher $\mathrm{CH}_{4}$ emissions, but their influence seemed to be less important at our sites.

The $\mathrm{CH}_{4}$ emissions of P-POLDER were higher than emissions of the cultivation sites but significantly smaller compared to the near-natural sites (Table 3). They were comparable to emissions of irrigation ditches at a nearby Sphagnum cultivation

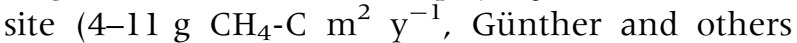
2017). In contrast, Franz and others (2016) reported $40 \mathrm{~g} \mathrm{CH}_{4}-\mathrm{C} \mathrm{m}^{2} \mathrm{y}^{-1}$ for a re-wetted rich fen. As in other chamber studies (for example, Günther and others 2017), we could not determine episodic ebullition fluxes, which might have played a role especially at P-POLDER. Therefore, $\mathrm{CH}_{4}$ fluxes estimated here probably represent a lower limit of the 'real fluxes'.
Nitrous oxide $\left(\mathrm{N}_{2} \mathrm{O}\right)$

$\mathrm{N}_{2} \mathrm{O}$ emissions were mainly relevant for the GHG balances of the ditch irrigation site (Fig. 7A). Annual balances at this site were comparable to those of arable land (Tiemeyer and others 2020), and even the $\mathrm{N}_{2} \mathrm{O}$ emissions of D-DRIP are comparable to low-intensity grassland on bog peat (LeiberSauheitl and others 2014). Emission peaks at DDITCH (Fig. 7B) coincided with a re-rise of WTD after a dry period and high concentrations of nitrate in the soil pore water (Fig. 7C). The respective $\mathrm{NO}_{3}{ }^{-}$concentrations of the irrigation ponds were not elevated, hinting towards an origin of $\mathrm{N}$ in peat mineralization during the preceding dry period. With a rising WTD, $\mathrm{NO}_{3}{ }^{-}$was probably converted to $\mathrm{N}_{2} \mathrm{O}$ by incomplete denitrification. Unfortunately, it is possible that this peak emission was missed in 2018: A similar re-rise of WTD combined with higher concentrations of $\mathrm{NO}_{3}{ }^{-}$in the soil pore water was observed in August 2018, but the respective $\mathrm{CH}_{4} / \mathrm{N}_{2} \mathrm{O}$ campaign could not be conducted. A lack of vegetation which could take up $\mathrm{N}$ from the soil water also seems to contribute to the observed pattern. High $\mathrm{N}_{2} \mathrm{O}$ emissions from bare peat were also reported by other studies (Marushchak and others 2011), emphasizing the risk of high $\mathrm{N}_{2} \mathrm{O}$ emission under suboptimum plant growth conditions even at unfertilized sites.

\section{Greenhouse Gas Balances}

Altogether, the GHG emissions were higher than those of Sphagnum farming on less degraded peat soils (Beyer and Höper 2015; Günther and others 2017) mainly because of more unfavourable $\mathrm{CO}_{2}$ 
exchange in our case and the different degrees of decomposition of the cultivation sites. It also has to be taken into account that 2018 was an extraordinary hot and dry year and that drought substantially affected GHG exchange. Interestingly, the near-natural sites proved to be resilient regarding the WTD due to its ability to oscillate, but to be very sensitive regarding the GHG exchange. Here, the highest annual balances were quantified. This result must not be misinterpreted in a way that nearnatural sites should be used as Sphagnum farming sites as our cultivation sites have a land-use legacy of carbon emissions equivalent to several metres of peat and as near-natural sites are irreplaceable in terms of biodiversity. Further, the temporal dynamic of the radiative forcing impact of natural sites, which is dominated by $\mathrm{CO}_{2}$ in the long term (Frolking and others 2006), has to be considered. Despite the high $\mathrm{CH}_{4}$ emissions, M-NAT was still accumulating C in 2017.

\section{Impact of Sphagnum Harvest at the Near-natural Site}

Harvesting the upper $5-\mathrm{cm}$ vegetation at M-HAR resulted in higher $\mathrm{CH}_{4}$ emissions and-on average-lower $\mathrm{CO}_{2}$ emissions. Effectively, it removed the active green Sphagnum horizon and moved the peat surface towards the water table, which resulted in a decreased $\mathrm{CO}_{2}$ uptake in the first year, but lower $\mathrm{CO}_{2}$ emissions than M-NAT in the dry second year. Reduced oxidation in the shallower Sphagnum horizon might be the reason for the increased $\mathrm{CH}_{4}$ emission. This pattern of higher $\mathrm{CH}_{4}$ emissions and a reduced $\mathrm{CO}_{2}$ uptake followed by a rapid plant recovery was also reported by Murray and others (2017) for a Canadian donor site. However, wetter conditions and flattening of the surface of harvested sites could change plant compositions in the long-term (Guene-Nanchen and others 2019). M-HAR showed slightly lower Sphagnum covers and slightly higher covers of vascular plants (especially Rhynchospora alba and Molinia caerulea). GPP recovered in 2018, but GPP and $R_{\text {eco }}$ were higher at M-NAT in both years. It has to be considered that the 'drowned' replicate (Fig. 3) is included in the average GHG values. Silvan and others (2017) harvested down to a depth of $30 \mathrm{~cm}$ and also described a rapid recovery of Sphagnum cover and $\mathrm{CO}_{2}$ sequestration. Under optimum conditions, re-growth of Sphagnum could even facilitate yearly harvests (Krebs and others 2018). However, the depth of cutting needs to be carefully adjusted when harvesting Sphagnum farming sites.

\section{Impact of Different Irrigation Systems and Initial Effects}

Three different irrigation systems were investigated in this study. In Drenth, drip irrigation (D-DRIP) provided slightly higher WTDs compared to ditch irrigation (D-DITCH), while Provinzialmoor became very dry in 2018 due to a lack of sufficient irrigation water and accidentally continuing drainage. However, despite the apparently hydrological favourable conditions in Drenth, vegetation developed better and $\mathrm{CO}_{2}$ emissions were lower in Provinzialmoor. In this context, it is important to emphasize that the vegetation development at the GHG plots was in line with the overall vegetation development at the cultivation sites (Grobe and others 2021). A number of factors might have contributed to these surprising results: differences in soil properties, differences in meteorological conditions, the presence of vascular plants, quality of the irrigation water and initial effects.

Soil properties were slightly more favourable at Provinzialmoor (Table 1), which might be the result of the preceding multi-annual inundation (especially the lower BD and higher $\epsilon$ ). While this did not prevent dry conditions in the uppermost soil layer, which is relevant for the peat mosses, the vascular plants might have profited from the higher field capacity and in turn positively influenced peat moss development.

The shape of the cultivation areas and the surrounding environment would suggest higher evapotranspiration and lower humidity at Drenth (narrow strip surrounded by ongoing peat extraction) than at Provinzialmoor (square surrounded by re-wetted peatlands). However, D-DRIP even showed slightly higher humidity compared to PMIX in 2018, although this might have been caused by the drip irrigation itself. Furthermore, mean peat thickness was only $45 \mathrm{~cm}$ in Drenth compared to $90 \mathrm{~cm}$ in Provinzialmoor, which could have affected the ability of mosses to cope with prolonged periods of increased evaporation (Dixon and others 2017).

The irrigation water used in Drenth during dry summer periods had a lower quality regarding $\mathrm{pH}$ and nutrient concentrations than the polders in Provinzialmoor. In particular, higher amounts of calcium were measured. At single dates, concentrations exceeded $20 \mathrm{mg} \mathrm{l}^{-1}$, an amount possibly negatively affecting peat moss health (Vicherová and others 2015). Higher concentrations were observed only in the irrigation ponds and not in the soil pore water at measurement plots. However, temporal inundation at D-DITCH and aboveground 
drip irrigation at D-DRIP could have delivered detrimental amounts.

Especially in the initial phase of Sphagnum growth, a sufficient water supply is essential (Pouliot and others 2015). Before the installation of drip irrigation, site D-DRIP was irrigated via subsurface drain pipes, which did not provide sufficient water in the first months after spreading of moss fragments. It is likely that the well-working drip irrigation could not compensate for damages in the phase of Sphagnum establishment. Furthermore, storms and freezing damaged parts of the Drenth area in early 2017, whereas the Provinzialmoor area was hardly affected and also profited from a relatively wet year 2016 .

\section{Areal GHG Balances}

Altogether, drip irrigation (D-DRIP) generated the lowest areal GHG balance because the low sitespecific emissions in Provinzialmoor were compromised by the large areal contribution of the irrigation polder. However, emissions per ton of extractable Sphagnum biomass were lowest in Provinzialmoor due to the better vegetation development.

We need to stress that differences between the investigated irrigation systems (Table 4) have to be interpreted with caution. They might be the result of the previous re-wetting of Provinzialmoor as well as the result of disturbances in the initial phase in Drenth. In contrast to Provinzialmoor, it was possible to add groundwater in dry periods in Drenth, considerably reducing the areal contribution of the irrigation system.

Furthermore, the assumptions made to derive areal balances induced uncertainties. The water deficit in Drenth $(500 \mathrm{~mm})$ and the resulting theoretical polder size for Provinzialmoor were slightly higher than deficits calculated for a neighbouring Sphagnum farming site. Brust and others (2018) specified a mean deficit of $160 \mathrm{~mm}$ and a deficit of $320 \mathrm{~mm}$ in dry years. However, they also recorded a deficit of $636 \mathrm{~mm}$ in an extremely dry year, supporting our theoretical polder size. Although emissions from site P-POLDER resemble those from irrigation ditches of this neighbouring site (Günther and others 2017), literature values for emissions from peat dams vary considerably. For example, Vybornova and others (2019) report 31.5 t $\mathrm{CO}_{2}$-eq. ha ${ }^{-1} \mathrm{y}^{-1}$ for bare peat dams, two thirds of this emission being $\mathrm{CO}_{2}$ and about one third being $\mathrm{N}_{2} \mathrm{O}$. This value would be seven times larger than the value used in this study.
To optimize both GHG balances and productivity per area, future designs for Sphagnum farming should keep areas of dams and open water as small as possible while avoiding all unnecessary water losses and ensuring a sufficient water supply in dry summer periods. As long as the sites have not yet developed an active acrotelm, irrigation and thus space for water storage will be needed. In Drenth, peat mosses grew better in closer distance to ditches (Grobe and others 2021) and ditches could be cut in closer distance (5 m, Gaudig and others 2017). However, this will considerably influence both the maintenance costs and the GHG balance, as emissions of ditches are expected to be higher than the emissions of cultivation areas. Due to the challenging hydrological conditions, the irrigation via ditches seems to be only recommendable for highly decomposed sites if they were inundated before. Drip irrigation might better maintain favourable moisture conditions, but requires water of a better quality than ditch irrigation.

Finally, even though optimum conditions could not be provided, Sphagnum farming on former peat extraction sites still offers a considerable GHG mitigation compared to average emissions from cropland (33.7 t CO 2 -eq. ha ${ }^{-1} \mathrm{y}^{-1}$ ) and grassland (30.4 t CO $\mathrm{CO}_{2}$-eq. ha ${ }^{-1} \mathrm{y}^{-1}$ ) in Germany (Tiemeyer and others 2020). In the presented balances, global warming potentials over 100 years were used. When considering longer time frames, the most important goal of peatland restoration and paludiculture projects is to quickly stop the sites from emitting $\mathrm{CO}_{2}$ to the atmosphere (Günther and others 2020).

\section{ACKNOWLEDGEMENTS}

This research was funded by the Lower Saxony Ministry for Nutrition, Agriculture and Consumer Protection (ML, AZ 105.1-3234/1-13-3) and the German Federal Environmental Foundation (DBU, AZ 33305/01-33/0). The permissions granted by the Weser-Ems Office for Regional State Development (State Bog Administration) and the County Emsland have facilitated the project. We thank our project partners at Klasmann-Deilmann $\mathrm{GmbH}$ for the productive cooperation. We gratefully thank two anonymous reviewers for their knowledgeable and constructive comments. We also want to express our thanks to Kerstin Gilke and Andrea Oehns-Rittgerodt for gas chromatograph analyses; Sabine Wathsack, Ute Tambor, Thomas Viohl and Claudia Wiese for water, soil and biomass analysis, Frank Hegewald and Dirk Lempio for technical assistance in the field, and Arndt Piayda for data on 
hydraulic conductivity and soil sampling together with Mareille Wittnebel. Finally, we would also like to thank the students who helped in the field and in the laboratory.

\section{FUNDING}

Open Access funding enabled and organized by Projekt DEAL.

Open Access This article is licensed under a Creative Commons Attribution 4.0 International License, which permits use, sharing, adaptation, distribution and reproduction in any medium or format, as long as you give appropriate credit to the original author(s) and the source, provide a link to the Creative Commons licence, and indicate if changes were made. The images or other third party material in this article are included in the article's Creative Commons licence, unless indicated otherwise in a credit line to the material. If material is not included in the article's Creative Commons licence and your intended use is not permitted by statutory regulation or exceeds the permitted use, you will need to obtain permission directly from the copyright holder. To view a copy of this licence, visit http://creativecommons.org/li censes/by/4.0/.

\section{REFERENCES}

Beyer C, Höper H. 2015. Greenhouse gas exchange of rewetted bog peat extraction sites and a Sphagnum cultivation site in northwest Germany. Biogeosciences 12(7):2101-2117.

Blankenburg J. 2004. Praktische Hinweise zur optimalen Wiedervernässung von Torfabbauflächen (in German). Geofakten 14, Niedersächsisches Landesamt für Bodenforschung, Bremen. $1-11$.

Brown C, Strack M, Price JS. 2017. The effects of water management on the $\mathrm{CO}_{2}$ uptake of Sphagnum moss in a reclaimed peatland. Mires and Peat 20(5):1-15.

Brust K, Krebs M, Wahren A, Gaudig G, Joosten H. 2018. The water balance of a Sphagnum farming site in north-west Germany. Mires and Peat 20(10):1-12.

Buttler A, Grosvernier P, Matthey Y. 1998. Development of Sphagnum fallax diaspores on bare peat with implications for the restoration of cut-over bogs. Journal of Applied Ecology 35:800-810.

Dettmann U, Bechtold M, Viohl T, Piayda A, Sokolowsky L, Tiemeyer B. 2019. Evaporation experiments for the determination of hydraulic properties of peat and other organic soils: An evaluation of methods based on a large dataset. Journal of Hydrology 575:933-944.

Dixon SJ, Kettridge N, Moore PA, Devito KJ, Tilak AS, Petrone RM, Mendoza CA, Waddington JM. 2017. Peat depth as a control on moss water availability under evaporative stress. Hydrological Processes 31:4107-4121.
Drösler M. 2005. Trace gas exchange and climatic relevance of bog ecosystems, Southern Germany. Doctoral Dissertation at the Technical University of Munich. 102-130.

Durner W. 1994. Hydraulic conductivity estimation for soils with heterogeneous pore structure. Water Resources Research 30:211-223.

Emmel M. 2008. Growing ornamental plants in Sphagnum biomass. Acta Horticulturae 779:173-178.

Falge E, Baldocchi D, Olson R, Anthoni P, Aubinet M, Bernhofer C, Burba G, Ceulemans R, Clement R, Dolman H, Granier A, Gross P, Grünwald T, Hollinger D, Jensen NO, Katul G, Keronen P, Kowalski A, Lai CT, Law BE, Meyers T, Moncrieff J, Moors E, Munger JW, Pilegaard K, Rannik Ü, Rebmann C, Suyker A, Tenhunen J, Tu K, Verma S, Vesala T, Wilson K, Wofsy S. 2001. Gap filling strategies for defensible annual sums of net ecosystem exchange. Agricultural and Forest Meteorology 107:43-69.

Franz D, Koebsch F, Larmanou E, Augustin J, Sachs T. 2016. High net $\mathrm{CO}_{2}$ and $\mathrm{CH}_{4}$ release at a eutrophic shallow lake on a formerly drained fen. Biogeosciences 13:3051-3070.

Frolking S, Roulet NT, Fuglestvedt J. 2006. How northern peatlands influence the Earth's radiative budget: Sustained methane emission versus sustained carbon sequestration. Journal of Geophysical Research 111:1-10.

Fuß R. 2020. gasfluxes: Greenhouse Gas Flux Calculation from Chamber Measurements. $\mathrm{R}$ package version $0.4-4$.

Gaudig G, Krebs M. 2016. Torfmooskulturen als Ersatzlebensraum - Nachhaltige Moornutzung trägt zum Artenschutz bei (in German). Biologie in Unserer Zeit 46(4):251-257.

Gaudig G, Krebs M, Joosten H. 2017. Sphagnum farming on cutover bog in NW Germany: Long-term studies on Sphagnum growth. Mires and Peat 20(4):1-19.

Gaudig G, Krebs M, Prager A, Wichmann S, Barney M, Caporn SJM, Emmel M, Fritz C, Graf M, Grobe A, Pacheco SG. 2018. Sphagnum farming from species selection to the production of growing media: a review. Mires and Peat 20(13):1-30.

Gaudig G, Krebs M, Joosten H. 2020. Sphagnum growth under N saturation: interactive effects of water level and P or K fertilization. Plant Biology 22:394-403.

Graf M, Bredemeier B, Grobe A, Köbbing JF, Oestmann J, Rammes D, Reich M, Tiemeyer B, Zoch L. 2017. Torfmooskultivierung auf Schwarztorf: ein neues Forschungsprojekt in Niedersachsen (in German). Telma 47:1109-1128.

Gray A, Levy PE, Cooper MDA, Jones T, Gaiawyn J, Leeson SR, Ward SE, Dinsmore KJ, Drewer J, Sheppard LJ, Ostle NJ, Evans CD, Burden A, Zieliński P. 2013. Methane indicator values for peatlands: A comparison of species and functional groups. Global Change Biology 19:1141-1150.

Greenup AL, Bradford MA, Mcnamara NP, Ineson P, Lee JA. 2000. The role of Eriophorum vaginatum in $\mathrm{CH}_{4}$ flux from an ombrotrophic peatland. Plant and Soil 227:265-272.

Grobe A, Tiemeyer B, Graf M. 2021. Recommendations for successful establishment of Sphagnum farming on shallow highly decomposed peat. Mires and Peat (accepted)

Guêné-Nanchen M, Hugron S, Rochefort L. 2019. Harvesting surface vegetation does not impede self-recovery of Sphagnum peatlands. Restoration Ecology 27:178-188.

Günther A, Huth V, Jurasinski G, Glatzel S. 2015. The effect of biomass harvesting on greenhouse gas emissions from a rewetted temperate fen. Global Change Biology Bioenergy 7:1092-1 106. 
Günther A, Jurasinski G, Albrecht K, Gaudig G, Krebs M, Glatzel S. 2017. Greenhouse gas balance of an establishing Sphagnum culture on a former bog grassland in Germany. Mires and Peat 20(2):1-16.

Günther A, Barthelmes A, Huth V, Joosten H, Jurasinski G, Koebsch F, Couwenberg J. 2020. Prompt rewetting of drained peatlands reduces climate warming despite methane emissions. Nature Communications 11:1-14.

Hahn J, Köhler S, Glatzel S, Jurasinski G. 2015. Methane exchange in a coastal fen in the first year after flooding - A systems shift. PLoS One 10(10):1-25.

Helfter C, Campbell C, Dinsmore KJ, Drewer J, Coyle M, Anderson M, Skiba U, Nemitz E, Billett MF, Sutton MA. 2015. Drivers of long-term variability in $\mathrm{CO}_{2}$ net ecosystem exchange in a temperate peatland. Biogeosciences 12:17991811 .

Henneberg A, Elsgaard L, Sorrell BK, Brix H, Petersen SO. 2015. Does Juncus effusus enhance methane emissions from grazed pastures on peat? Biogeosciences 12:5667-5676.

Hüppi R, Felber R, Krauss M, Six J, Leifeld J, Fuß R. 2018. Restricting the nonlinearity parameter in soil greenhouse gas flux calculation for more reliable flux estimates. PLoS One 13(7):1-17.

Hurkuck M, Brümmer C, Kutsch WL. 2016. Near-neutral carbon dioxide balance at a seminatural, temperate bog ecosystem. Journal of Geophysical Research: Biogeosciences 121:370384.

Hütsch BW. 2001. Methane oxidation in non-flooded soils as affected by crop production-invited paper. European Journal of Agronomy 14:237-260.

IUSS Working Group WRB. 2015. World Reference Base for Soil Resources 2014, update 2015. International soil classification system for naming soils and creating legends for soil maps. Food and Agriculture Organization, Rome (World Soil Resources Reports, 106).

Johnson KA, Goody RS. 2011. The original Michaelis constant: translation of the 1913 Michaelis-Menten paper. Biochemistry 50(39):8264-8269.

Juutinen S, Moore TR, Bubier JL, Arnkil S, Humphreys E, Marincak B, Roy C, Larmola T. 2018. Long-term nutrient addition increased $\mathrm{CH}_{4}$ emission from a bog through direct and indirect effects. Scientific Reports 8(1):1-11.

Krebs M, Gaudig G, Matchutadze I, Joosten H. 2018. Sphagnum regrowth after cutting. Mires and Peat 20(12):1-20.

Leiber-Sauheitl K, Fuß R, Voigt C, Freibauer A. 2014. High $\mathrm{CO}_{2}$ fluxes from grassland on histic gleysol along soil carbon and drainage gradients. Biogeosciences 11:749-761.

Leroy F, Gogo S, Guimbaud C, Bernard-Jannin L, Yin X, Belot G, Shuguang W, Laggoun-Défarge F. 2019. $\mathrm{CO}_{2}$ and $\mathrm{CH}_{4}$ budgets and global warming potential modifications in Sphagnumdominated peat mesocosms invaded by Molinia caerulea. Biogeosciences 16:4085-4095.

Liu H, Lennartz B. 2019. Hydraulic properties of peat soils along a bulk density gradient - A meta study. Hydrological Processes 33:101-114.

Livingston GP, Hutchinson GL. 1995. Enclosure-based measurement of trace gas exchange: applications and sources of error. Matson PA, Harris RC, editors. Biogenic trace gases: measuring emissions from soil and water. Oxford: Blackwell Science. 14-51.

Lloyd J, Taylor JA. 1994. On the Temperature Dependence of Soil Respiration. Functional Ecology 8:315-323.
Londo G. 1976. The decimal scale for releves of permanent quadrats. Vegetatio 33:61-64.

Marushchak ME, Pitkämäki A, Koponen H, Biasi C, Seppälä M, Martikainen PJ. 2011. Hot spots for nitrous oxide emissions found in different types of permafrost peatlands. Global Change Biology 17:2601-2614.

McCarter CPR, Price JS. 2015. The hydrology of the Bois-des-Bel peatland restoration: Hydrophysical properties limiting connectivity between regenerated Sphagnum and remnant vacuum harvested peat deposit. Ecohydrology 8:173-187.

McNeil P, Waddington JM. 2003. Moisture controls on Sphagnum growth and $\mathrm{CO}_{2}$ exchange on a cutover bog. Journal of Applied Ecology 40:354-367.

Murray KR, Borkenhagen AK, Cooper DJ, Strack M. 2017. Growing season carbon gas exchange from peatlands used as a source of vegetation donor material for restoration. Wetlands Ecology and Management 25:501-515.

Muster C, Gaudig G, Krebs M, Joosten H. 2015. Sphagnum farming: the promised land for peat bog species? Biodiversity and Conservation 24:1989-2009.

Myhre G, Shindell D, Bréon FM, Collins W, Fuglestvedt J, Huang J, Koch D, Lamarque JF, Lee D, Mendoza B, Nalajima T, Robock A, Stephens G, Takemura T, Zhang H. 2013. Climate Change 2013: The Physical Science Basis. Working Group I contribution to the IPCC Fifth Assessment Report. Intergovernmental Panel on Climate Change. Cambridge: Cambridge University Press.

Nugent KA, Strachan IB, Strack M, Roulet NT, Rochefort L. 2018. Multi-year net ecosystem carbon balance of a restored peatland reveals a return to carbon sink. Global Change Biology 24:5751-5768.

Pedersen AR, Petersen SO, Schelde K. 2010. A comprehensive approach to soil-atmosphere trace-gas flux estimation with static chambers. European Journal of Soil Science 61:888902.

Pouliot R, Hugron S, Rochefort L. 2015. Sphagnum farming: A long-term study on producing peat moss biomass sustainably. Ecological Engineering 74:135-147.

Price JS, Whitehead GS. 2001. Developing hydrologic thresholds for Sphagnum recolonization on an abandoned cutover bog. Wetlands 21:32-40.

Quinty F, Rochefort L. 2003. Peatland Restoration Guide, Second Edition. Canadian Sphagnum Peat Moss Association (St. Albert, $\mathrm{AB}$ ) and New Brunswick Department of Natural Resources and Energy (Fredericton, NB).

R Core Team, 2019. R: A language and environment for statistical computing, R Foundation for Statistical Computing, Vienna, Austria.

Regina K, Nykänen H, Silvola J, Martikainen PJ. 1996. Fluxes of nitrous oxide from boreal peatlands as affected by peatland type, water table level and nitrification capacity. Biogeochemistry 35:401-418.

Rigney C, Wilson D, Renou-Wilson F, Müller C, Moser G, Byrne KA. 2018. Greenhouse gas emissions from two rewetted peatlands previously managed for forestry. Mires and Peat $21(24): 1-23$.

Silvan N, Jokinen K, Näkkilä J, Tahvonen R. 2017. Swift recovery of Sphagnum carpet and carbon sequestration after shallow Sphagnum biomass harvesting. Mires and Peat 20(1):1-11. 
Strack M, Waddington JM, Lucchese MC, Cagampan JP. 2009. Sphagnum-dominated peatland: results from an extreme drought field experiment. Ecohydrology 2:454-461.

Tiemeyer B, Freibauer A, Borraz EA, Augustin J, Bechtold M, Beetz S, Beyer C, Ebli M, Eickenscheidt T, Fiedler S, Förster C, Gensior A, Giebels M, Glatzel S, Heinichen J, Hoffmann M, Höper H, Jurasinski G, Laggner A, Leiber-Sauheitl K, PeichlBrak M, Drösler M. 2020. A new methodology for organic soils in national greenhouse gas inventories: Data synthesis, derivation and application. Ecological Indicators 109: 105838.

Tuittila ES, Komulainen VM, Vasander H, Nykanen H, Martikainen PJ, Laine J. 2000. Methane dynamics of a restored cut-away peatland. Global Change Biology 6:569-581.

Turetsky MR, Kotowska A, Bubier J, Dise NB, Crill P, Hornibrook ERC, Minkkinen K, Moore TR, Myers-Smith IH, Nykänen H, Olefeldt D, Rinne J, Saarnio S, Shurpali N, Tuittila ES, Waddington JM, White JR, Wickland KP, Wilmking M. 2014. A synthesis of methane emissions from 71 northern, temperate, and subtropical wetlands. Global Change Biology 20:2183-2197.

van Genuchten MT. 1980. A closed-form equation for predicting the hydraulic conductivity of unsaturated soils. Soil Science Society of America 44:892-898.

Vanselow-Algan M, Schmidt SR, Greven M, Fiencke C, Kutzbach L, Pfeiffer EM. 2015. High methane emissions dominated annual greenhouse gas balances 30 years after bog rewetting. Biogeosciences 12:4361-4371.

Vicherová E, Hájek M, Hájek T. 2015. Calcium intolerance of fen mosses: Physiological evidence, effects of nutrient availability and successional drivers. Perspectives in Plant Ecology, Evolution and Systematics 17:347-359.
Vybornova O, van Asperen H, Pfeiffer E, Kutzbach L. 2019. High $\mathrm{N}_{2} \mathrm{O}$ and $\mathrm{CO}_{2}$ emissions from bare peat dams reduce the climate mitigation potential of bog rewetting practices. Mires and Peat 24(4):1-22.

Waddington JM, Day SM. 2007. Methane emissions from a peatland following restoration. Journal of Geophysical Research: Biogeosciences 112(3):1-11.

Waddington JM, Price JS. 2000. Effect of peatland drainage, harvesting, and restoration on atmospheric water and carbon exchange. Physical Geography 21:433-451.

Webb EK, Pearman GI, Leuning R. 1980. Correction of flux measurements for density effects due to heat and water vapour transfer. Quarterly Journal of the Royal Meteorological Society 106:85-100.

Wichtmann W, Schröder C, Joosten H, Eds. 2016. Paludiculture - Productive Use of Wet Peatlands. Climate Protection, Biodiversity, Regional Economic Benefits. Stuttgart: Schweizerbart Science Publishers.

Wilson D, Blain D, Cowenberg J, Evans CD, Murdiyarso D, Page SE, Renou-Wilson F, Rieley JO, Sirin AS, M. Tuittila E-S. . 2016a. Greenhouse gas emission factors associated with rewetting of organic soils. Mires and Peat 17(4):1-28.

Wilson D, Farrell CA, Fallon D, Moser G, Müller C, RenouWilson F. 2016b. Multiyear greenhouse gas balances at a rewetted temperate peatland. Global Change Biology 22:4080-4095.

Zoch L, Reich M. 2020. Torfmooskultivierungsflächen als neuer Lebensraum für Moorlibellen (in German). Libellula 39(1/ 2):27-48 